\title{
Processes controlling the Si-isotopic composition in the Southern Ocean and application for paleoceanography
}

\author{
F. Fripiat ${ }^{1,2}$, A.-J. Cavagna ${ }^{3}$, F. Dehairs ${ }^{3}$, A. de Brauwere ${ }^{3,4}$, L. André ${ }^{1}$, and D. Cardinal ${ }^{1, *}$ \\ ${ }^{1}$ Section of Mineralogy and Petrography, Royal Museum for Central Africa, Tervuren, Belgium \\ ${ }^{2}$ Department of Earth and Environmental Sciences, Université Libre de Bruxelles, Brussels, Belgium \\ ${ }^{3}$ Analytical and Environmental Chemistry \& Earth System Sciences, Vrije Universiteit Brussel, Brussels, Belgium \\ ${ }^{4}$ Institute of Mechanics, Materials and Civil Engineering (IMMC), Université Catholique de Louvain, Louvain-la-Neuve, \\ Belgium \\ *now at: Laboratoire d'Océanographie et du Climat: Expérimentations et Approches Numériques (LOCEAN), Université \\ Pierre et Marie Curie, Paris, France
}

Correspondence to: F. Fripiat (ffripiat@ulb.ac.be)

Received: 8 September 2011 - Published in Biogeosciences Discuss.: 17 October 2011

Revised: 25 April 2012 - Accepted: 16 May 2012 - Published: 6 July 2012

\begin{abstract}
Southern Ocean biogeochemical processes have an impact on global marine primary production and global elemental cycling, e.g. by likely controlling glacial-interglacial $p \mathrm{CO}_{2}$ variation. In this context, the natural silicon isotopic composition $\left(\delta^{30} \mathrm{Si}\right)$ of sedimentary biogenic silica has been used to reconstruct past Si-consumption:supply ratios in the surface waters. We present a new dataset in the Southern Ocean from a IPY-GEOTRACES transect (BonusGoodHope) which includes for the first time summer $\delta^{30} \mathrm{Si}$ signatures of suspended biogenic silica (i) for the whole water column at three stations and (ii) in the mixed layer at seven stations from the subtropical zone up to the Weddell Gyre. In general, the isotopic composition of biogenic opal exported to depth was comparable to the opal leaving the mixed layer and did not seem to be affected by any diagenetic processes during settling, even if an effect of biogenic silica dissolution cannot be ruled out in the northern part of the Weddell Gyre. We develop a mechanistic understanding of the processes involved in the modern Si-isotopic balance, by implementing a mixed layer model. We observe that the accumulated biogenic silica (sensu Rayleigh distillation) should satisfactorily describe the $\delta^{30} \mathrm{Si}$ composition of biogenic silica exported out of the mixed layer, within the limit of the current analytical precision on the $\delta^{30} \mathrm{Si}$. The failures of previous models (Rayleigh and steady state) become apparent especially at the end of the productive period in the mixed layer, when biogenic silica production and export are
\end{abstract}

low. This results from (1) a higher biogenic silica dissolution:production ratio imposing a lower net fractionation factor and (2) a higher Si-supply:Si-uptake ratio supplying light $\mathrm{Si}$-isotopes into the mixed layer. The latter effect is especially expressed when the summer mixed layer becomes strongly Si-depleted, together with a large vertical silicic acid gradient, e.g. in the Polar Front Zone and at the Polar Front.

\section{Introduction}

In the Southern Ocean, the deep nutrient-rich waters ascend into the surface layer south of the Polar Front (PF), and are returned to the subsurface northward before the available pools of nitrogen and phosphorus are fully used by phytoplankton. In contrast, silicic acid $\left(\mathrm{Si}[\mathrm{OH}]_{4}\right)$ becomes strongly depleted by diatom growth (Sarmiento et al., 2004). The balance between the efficiency of the biological pump (e.g. its ability to strip nutrients out of the mixed layer) and deep ocean ventilation releasing $\mathrm{CO}_{2}$ are both likely to control the atmospheric $\mathrm{CO}_{2}$ concentrations on glacial/interglacial timescales (Anderson et al., 2002, 2009; Brzezinski et al., 2002; Sigman et al., 2010).

The $\delta^{30} \mathrm{Si}$ signatures of biogenic silica $\left(={ }^{30} \mathrm{R}_{\mathrm{bSiO}}:{ }^{30} \mathrm{R}_{\text {standard }}-1\right.$, reported in permil units, \%o, where ${ }^{30} \mathrm{R}={ }^{30} \mathrm{Si}:{ }^{28} \mathrm{Si}$ ) are a proxy of Si-nutrient utilization in paleoceanography, and have been used to formulate and 
test hypotheses on both Southern Ocean productivity and fluctuations in atmospheric $p \mathrm{CO}_{2}$ over glacial cycles (De La Rocha et al., 1998; Anderson et al., 2002; Brzezinski et al., 2002; De La Rocha, 2006; Beucher et al., 2007). During silicic acid consumption by diatoms, the lighter $\mathrm{Si}$ isotope $\left({ }^{28} \mathrm{Si}\right)$ is preferentially consumed, leaving the silicic acid pool enriched in heavy Si-isotope $\left({ }^{30} \mathrm{Si}\right.$ ) (De La Rocha et al., 1997). Such preferential incorporation of ${ }^{28} \mathrm{Si}$ into biogenic silica $\left(\mathrm{bSiO}_{2}\right)$ is defined by a fractionation factor $\left({ }^{30} \varepsilon\right)$, which is equivalent to the ratio of the reaction rates of the heavy $\left({ }^{30} \mathrm{k}\right)$ and light $\left({ }^{28} \mathrm{k}\right)$ Si-isotopes $\left(={ }^{30} \mathrm{k}:{ }^{28} \mathrm{k}-1\right.$, reported in permil units, \%o). Therefore, for a given set of conditions setting the supply of $\mathrm{Si}(\mathrm{OH})_{4}$, a relationship is expected between the decrease of $\mathrm{Si}(\mathrm{OH})_{4}$ concentration due to the Si-uptake and the increase of $\delta^{30} \mathrm{Si}$ of both $\mathrm{bSiO}_{2}$ and $\mathrm{Si}(\mathrm{OH})_{4}$ (De La Rocha et al., 1997). However, the calibration of this proxy in the modern ocean has still not been fully achieved and processes such as $\mathrm{Si}(\mathrm{OH})_{4}$ supply and $\mathrm{bSiO}_{2}$ dissolution can bias the expected relationship between $\mathrm{Si}(\mathrm{OH})_{4}$ concentration and $\delta^{30} \mathrm{Si}$ composition (Demarest et al., 2009). For example, contemporary isotopic compositions of biogenic silica vary widely in the Southern Ocean $(-0.5$ to $+2.5 \%$ ), while the isotopic range of silicic acid is smaller (from +1.5 to $3.4 \%$ ) (Varela et al., 2004; Cardinal et al., 2005, 2007; Fripiat et al., 2011a; Cavagna et al., 2011). None of the existing isotopic fractionation models are capable of reproducing these differences. This highlights the significant importance of fully understanding the different processes involved in contemporary Si-isotopic balances before applying this proxy to reconstruct past ocean environments.

New data from the summer Antarctic Circumpolar Current (ACC) are presented here, looking at the relationship between $\delta^{30} \mathrm{Si}_{\mathrm{Si}(\mathrm{OH})_{4}}$ and $\delta^{30} \mathrm{Si}_{\mathrm{bSiO}_{2}}$ in the mixed layer. Primary objectives are to (1) assess the processes controlling mixed layer ${ }^{30} \mathrm{Si}_{\mathrm{bSiO}_{2}}$ and across the water column, and (2) the impact of such processes on the relationship between the relative silicic acid utilisation and $\delta^{30} \mathrm{Si}$.

\section{Materials and methods}

\subsection{Sampling and hydrology}

Between 8 February and 8 March 2008, the GEOTRACESInternational Polar Year (IPY) BONUS-GoodHope (BGH) cruise aboard R/V Marion Dufresne covered a transect from Cape Basin to the north of the Weddell Gyre (up to $58^{\circ} \mathrm{S}$ ) centred around the $0^{\circ}$ meridian (Fig. 1). Biogenic silica was sampled (1) in the mixed layer at 7 stations crossing the different hydrographic regimes of the ACC, and (2) from a profile of the surface to the deep ocean at 3 stations. For these stations and others from the same cruise, the water column profiles of silicic acid $\delta^{30} \mathrm{Si}$ are discussed in an associated paper (Fripiat et al., 2011b). In the latter study, water masses

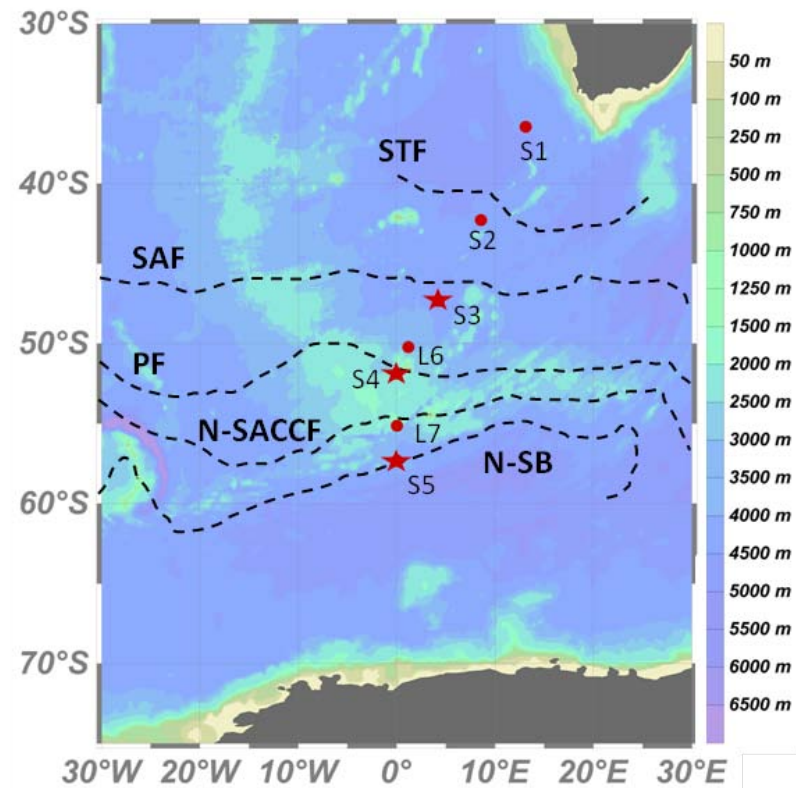

Fig. 1. Map of the study area with bathymetry and fronts (following Sokolov and Rintoul, 2009, and Swart et al., 2008): STF = SubTropical Front; SAF = SubAntarctic Front (middle branch); PF $=$ Polar Front (middle branch); N-SACCF = northern branch of the Southern ACC front; N-SB = northern branch of the Southern Boundary (SB). The area north of the STF is the SubTropical Zone (STZ); between STF and SAF the SubAntarctic Zone (SAZ); between the SAF and PF the Polar Front Zone (PFZ); between the PF and SB the Antarctic Zone (AZ), and south of the SB the northern part of the Weddell Gyre (WG). The stations where only the mixed layer was sampled are represented by dots. The stations where water column $\mathrm{bSiO}_{2}$ samples have been collected are represented by the stars. S refers to "super" stations and L to "large" stations. Mapping from Ocean Data View (Robert Schlitzer, available at http://odv.awi.de).

dynamics is suggested to be the main driving processes setting the distribution of the whole water-column $\delta^{30} \mathrm{Si}_{\mathrm{Si}(\mathrm{OH})_{4}}$.

Seawater was collected using a CTD Rosette equipped with 121 Niskin bottles. Water samples $(\sim 0.25$ to $\sim 101)$ were immediately filtered on $0.4 \mu \mathrm{m}$ Nuclepore polycarbonate membranes, using Perspex filtration units under the pressure of filtered air ( $0.4 \mu \mathrm{m}$ Nuclepore; $<2$ bar). Filtered water samples for silicic acid analyses were stored in acid-cleaned polypropylene (PP) bottles at room temperature in the dark. Nuclepore membranes were stored in polycarbonate Petri dishes and dried overnight at $50^{\circ} \mathrm{C}$. Large Volume Filtration Systems, hereafter referred to as "in situ pumps" (Challenger Oceanic Systems and Services, Surry, UK), sampled the complete water column by filtering 15 to 2501 of water through hydrophylic polyesthersufone membranes (SUPOR, $293 \mathrm{~mm} \emptyset, 0.45 \mu \mathrm{m})$. After partitioning the filters amongst the different end-users knowing the used filter surface, the pieces of SUPOR membranes were dried overnight at $50{ }^{\circ} \mathrm{C}$ and stored in Petri dishes in the dark at ambient temperature. 


\subsection{Analyses}

Samples were processed ashore (RMCA, Tervuren). For $\mathrm{bSiO}_{2}$ the membranes were subjected to a wet-alkaline digestion (adapted from Ragueneau et al., 2005) whereby $\mathrm{bSiO}_{2}$ is dissolved with a $0.2 \mu \mathrm{moll}^{-1} \mathrm{NaOH}$ solution $(\mathrm{pH} 13.3$ ) at $100{ }^{\circ} \mathrm{C}$ for $40 \mathrm{~min}$. As this digestion can also dissolve some lithogenic silica, we also analyzed aluminum (Al) in the digested solution to check for possible lithogenic contamination. Aluminium was determined using a Sector Field Inductively Coupled Plasma Mass Spectrometer (SF-ICPMS Element2, detection limit $=3 \mathrm{ppb},=3 *$ blank standard deviation). Using a Si:Al mass ratio of 3.74 for average crust (Taylor and McLennan, 1985), the lithogenic silica contributed to less than $2.5 \%$ of the $\mathrm{Si}$ in digested samples. The average distribution of clays in marine sediments along the BONUS-GoodHope transect is $<10 \%$ kaolinite, $>40 \%$ illite, $<20 \%$ smectite and $20-30 \%$ chlorite (Fütterer, 2006). The $\delta^{30} \mathrm{Si}$ signatures for such different types of clays published in previous studies are the following: kaolinite $-2.2 \pm 0.4 \%$ (Ziegler et al., 2005; Opfergelt et al., 2010); illite: $-0.9 \pm 0.2 \%$ (Douthitt, 1982) smectite: $-0.3 \pm 0.2 \%$ o (Georg et al., 2009). No $\delta^{30} \mathrm{Si}$ value is available for chlorite. Setting the chlorite $\delta^{30} \mathrm{Si}$ values to the one of kaolinite which maximizes the potential clay $\delta^{30} \mathrm{Si}$ contamination, we estimate an average clay $\delta^{30} \mathrm{Si}$ value for the BONUSGoodHope transect of -1.3 to $-1.0 \%$ using mass and isotopic balances from the expected distribution of clays. Taking the heavier BGH $\delta^{30} \mathrm{Si}_{\mathrm{bSiO}}$ and the calculated clay $\delta^{30} \mathrm{Si}$, with a lithogenic silica contamination of $2.5 \%$, the maximum potential contribution of such lithogenic $\mathrm{Si}$ to the measured $\delta^{30} \mathrm{Si}$ is $0.1 \%$. Such a lithogenic contribution can be neglected since it is similar to the achieved analytical precision for $\delta^{30} \mathrm{Si}$ determination (Abraham et al., 2008).

$\mathrm{Si}(\mathrm{OH})_{4}$ and $\mathrm{bSiO}_{2}$ concentrations were determined via a colorimetric method (Grasshoff et al., 1983) on the same samples as for $\mathrm{Si}$-isotopic composition. Since $\mathrm{Si}(\mathrm{OH})_{4}$ concentrations of surface and some subsurface samples at stations north of the Polar Front (PF) were too low $\left(<10 \mu \mathrm{moll}^{-1}\right)$ to directly apply the Si purification procedure required for Si-isotopic measurement (De La Rocha et al., 1996), a $\mathrm{Si}(\mathrm{OH})_{4}$ preconcentration step was performed. It was achieved using a protocol adapted by Brzezinski et al. (2003) and Reynolds et al. (2006) from the MAGIC method (Karl and Tien, 1992). Briefly, the method consists of one or two steps (depending of the Si-recovery of the first step) of the co-precipitation of $\mathrm{Si}(\mathrm{OH})_{4}$ with brucite $\left(\mathrm{Mg}(\mathrm{OH})_{2}\right)$, by increasing $\mathrm{pH}$ either with $\mathrm{NaOH}$ $1 \mu \mathrm{moll}^{-1}\left(20 \mathrm{mll}^{-1}\right.$ seawater, Reynolds et al., 2006) or $\mathrm{NH}_{4} \mathrm{OH} 13.5 \mu \mathrm{moll}^{-1}\left(6 \mathrm{mll}^{-1}\right.$ seawater Brzezinski et al., 2003). The precipitates were recovered by centrifugation and then redissolved with $\mathrm{HCl}$.

Silicon was co-precipitated with triethylamine molybdate (De La Rocha et al., 1996) with a minimum Si requirement of $\sim 1.5 \mu \mathrm{mol} \mathrm{Si}$. After combustion of the silicomolyb- date precipitate in covered $\mathrm{Pt}$ crucibles at $1000^{\circ} \mathrm{C}$, the pure cristobalite phase was transferred to pre-cleaned polypropylene vials. Dissolution of cristobalite was done in a dilute $\mathrm{HF} / \mathrm{HCl}$ mixture as described in Cardinal et al. (2003). Isotopic measurements were carried out on a Nu Plasma MCICP-MS (ULB, Brussels) using Mg external doping in dry plasma mode following Abraham et al. (2008). The average precision and reproducibility of the measurements are $\pm 0.1 \%$ ( $\pm 1 \mathrm{sd}$ ) for $\delta^{30} \mathrm{Si}$ (Reynolds et al., 2007). The accuracy of the measurements is checked on a daily basis on secondary reference materials (e.g. Diatomite) with known $\mathrm{Si}$ isotopic compositions resulting from an inter-comparison exercise (Reynolds et al., 2007).

\section{Results}

Surface $\delta^{30} \mathrm{Si}_{\mathrm{Si}(\mathrm{OH})_{4}}$ and $\left[\mathrm{Si}(\mathrm{OH})_{4}\right]$ display an opposite pattern with latitude (Table 1 and Fig. 2a). There is a ${ }^{30} \mathrm{Si}$ enrichment associated with the northward decreasing $\mathrm{Si}(\mathrm{OH})_{4}$ gradient across the Polar Front (PF), as observed earlier for $\delta^{30} \mathrm{Si}_{\mathrm{Si}(\mathrm{OH})_{4}}$ (Varela et al., 2004; Cardinal et al., 2005) and $\mathrm{Si}(\mathrm{OH})_{4}$ concentrations (Brzezinski et al., 2001; Quéguiner and Brzezinski, 2002). $\delta^{30} \mathrm{Si}_{\mathrm{bSiO}_{2}}$ values are systematically lighter than $\delta^{30} \mathrm{Si}_{\mathrm{Si}(\mathrm{OH})_{4}}$ values in agreement with the preferential uptake of ${ }^{28} \mathrm{Si}$ by diatoms. From the WG to the PFZ we observe a trend of increasing $\delta^{30} \mathrm{Si}_{\mathrm{bSiO}}$ following the $\delta^{30} \mathrm{Si}_{\mathrm{Si}(\mathrm{OH})_{4}}$ gradient, although the trend is much steeper for the former, as also observed by Varela et al. (2004) and Cardinal et al. (2007). North of the PFZ and SAZ, respectively, the $\delta^{30} \mathrm{Si}_{\mathrm{bSiO}}$ and ${ }^{30} \mathrm{Si}_{\mathrm{Si}(\mathrm{OH})_{4}}$ trend reverses, again displaying a steeper gradient for $\delta^{30} \mathrm{Si}_{\mathrm{bSiO}}$ values. This decoupling is reflected in the apparent fractionation factor $\left(\Delta^{30} \mathrm{Si}\right.$ $\left.=\delta^{30} \mathrm{Si}_{\mathrm{Si}(\mathrm{OH})_{4}}-\delta^{30} \mathrm{Si}_{\mathrm{bSiO}_{2}}\right)$ which varies widely with latitude (Fig. $2 b)$. Low $\Delta^{30} \mathrm{Si}$ values $(\sim 0.35 \pm 0.10 \%$ ) are observed at the PF and in the PFZ. Such low values seem to be a recurrent feature in the Southern Antarctic Circumpolar Current at low $\mathrm{Si}(\mathrm{OH})_{4}$ concentrations (Fig. 3). The mixed layer BONUS-GoodHope results for $\delta^{30} \mathrm{Si}_{\mathrm{Si}(\mathrm{OH})_{4}}(+1.8$ to $+3.2 \%$ o and for $\delta^{30} \mathrm{Si}_{\mathrm{bSiO}_{2}}(+0.3$ to $+2.5 \%$ o $)$ fall in the range reported for previous Southern Ocean studies $(+1.5$ to $+3.1 \%$; for $\delta^{30} \mathrm{Si}_{\mathrm{Si}(\mathrm{OH})_{4}} ;-0.5$ to $+2.6 \%$ of $\left.\delta^{30} \mathrm{Si}_{\mathrm{bSiO}}\right)$ (Varela et al., 2004; Cardinal et al., 2005, 2007; Fripiat et al., 2011a; Cavagna et al., 2011). For $\mathrm{bSiO}_{2}$, the previous studies are restricted to the Seasonal Ice Zone (SIZ), AZ, and PFZ. It is interesting to note that the range of $\delta^{30} \mathrm{Si}_{\mathrm{bSiO}_{2}}$ values are roughly two times those of $\delta^{30} \mathrm{Si}_{\mathrm{Si}(\mathrm{OH})_{4}}$ (Fig. 3a). A clear trend between $\Delta^{30} \mathrm{Si}$ and silicic acid concentration is observed in the mixed layer (Fig. 3b, non-linear regression using a power function, $\Delta^{30} \mathrm{Si}=0.40 *\left[\mathrm{Si}(\mathrm{OH})_{4}\right]^{0.36}$, $R^{2}=0.61$, p-value $\left.<0.01\right)$, similar to the one obtained with sponge spicules (Wille et al., 2010; Hendry and Robinson, 2012).

The water column profiles of $\mathrm{Si}(\mathrm{OH})_{4}$ and $\delta^{30} \mathrm{Si}_{\mathrm{Si}(\mathrm{OH})_{4}}$ clearly display ${ }^{30} \mathrm{Si}$ enrichment and $\mathrm{Si}(\mathrm{OH})_{4}$ depletion 
Table 1. $\mathrm{Si}(\mathrm{OH})_{4}$ and $\mathrm{bSiO}_{2}$ concentrations and isotopic compositions. Only the standard deviations for duplicates are shown. Bold numbers represents samples from in situ pumps. The mixed layer depth (MLD) has been determined using a combination of threshold density/temperature criterions relative to $10 \mathrm{~m}\left(\Delta T^{\circ} \mathrm{C}=0.2{ }^{\circ} \mathrm{C} ; \Delta \sigma=0.03\right.$ and $0.125 \mathrm{~kg} \mathrm{~m}^{-3}$; De Boyer Montégut et al., 2004). $\delta^{30} \mathrm{Si}-\mathrm{Si}(\mathrm{OH}) 4$ data are from Fripiat et al. (2011b).

\begin{tabular}{|c|c|c|c|c|c|c|}
\hline Station & $\begin{array}{r}\text { Depth } \\
\mathrm{m}\end{array}$ & $\begin{array}{r}\mathrm{Si}(\mathrm{OH})_{4} \\
\mu \mathrm{mol} \mathrm{1} 1^{-1}\end{array}$ & $\begin{array}{r}\delta^{30} \mathrm{Si}_{\mathrm{Si}(\mathrm{OH}) 4} \\
\% \text { sd }\end{array}$ & $\begin{array}{r}\text { Depth } \\
\mathrm{m}\end{array}$ & $\begin{array}{r}\mathrm{bSiO}_{2} \\
\mu \mathrm{mol} \mathrm{1}\end{array}$ & $\begin{array}{r}\delta^{30} \mathrm{Si}_{\mathrm{bSiO} 2} \\
\% \circ \pm \mathrm{sd}\end{array}$ \\
\hline Super 5 & 29 & 65.2 & $1.85 \pm 0.03$ & 30 & 0.36 & $0.28 \pm 0.04$ \\
\hline 16 March 2008 & 88 & 64.2 & 2.00 & 88 & 1.23 & 0.28 \\
\hline $00.02^{\circ} \mathrm{E}-57.32^{\circ} \mathrm{S}$ & 151 & 84.1 & $1.50 \pm 0.03$ & 140 & 0.12 & $-0.40 \pm 0.10$ \\
\hline \multirow[t]{12}{*}{$\mathrm{MLD}=58-115 \mathrm{~m}$} & 199 & 96.2 & $1.35 \pm 0.01$ & 250 & 0.23 & $0.16 \pm 0.01$ \\
\hline & 251 & 101.5 & $1.37 \pm 0.05$ & 400 & 0.18 & $0.27 \pm 0.03$ \\
\hline & 299 & 104.2 & $1.41 \pm 0.05$ & 700 & 0.10 & $0.26 \pm 0.02$ \\
\hline & 400 & 110.5 & $1.44 \pm 0.36$ & 1800 & 0.05 & $0.68 \pm 0.11$ \\
\hline & 499 & 117.2 & 1.47 & 2500 & 0.04 & $0.65 \pm 0.15$ \\
\hline & 700 & 116.5 & $1.44 \pm 0.20$ & 3200 & 0.04 & $0.72 \pm 0.12$ \\
\hline & 1003 & 120.0 & 1.27 & 3874 & $\mathbf{0 . 0 3}$ & $0.92 \pm 0.08$ \\
\hline & 1499 & 119.1 & 1.13 & & & \\
\hline & 1999 & 116.6 & $1.12 \pm 0.06$ & & & \\
\hline & 2500 & 119.7 & 1.43 & & & \\
\hline & 3000 & 117.2 & $1.11 \pm 0.08$ & & & \\
\hline & 3979 & 118.8 & 1.08 & & & \\
\hline Large 7 & 4 & 50.7 & 1.95 & 4 & 0.40 & $0.42 \pm 0.11$ \\
\hline 14 March 2008 & 39 & n.a. & n.a. & 39 & 0.72 & $0.53 \pm 0.04$ \\
\hline $00.03^{\circ} \mathrm{E}-55.14^{\circ} \mathrm{S}$ & 80 & 50.0 & $1.78 \pm 0.07$ & 80 & 0.38 & 0.50 \\
\hline \multicolumn{7}{|l|}{$\mathrm{MLD}=100-101 \mathrm{~m}$} \\
\hline Super 4 & 11 & 22.2 & 2.42 & 11 & 0.31 & 1.38 \\
\hline 11 March 2008 & 41 & n.a. & n.a. & 41 & 0.39 & 1.28 \\
\hline $00.03^{\circ} \mathrm{E}-51.87^{\circ} \mathrm{S}$ & 60 & n.a. & n.a. & 60 & 0.30 & $1.37 \pm 0.10$ \\
\hline \multirow[t]{12}{*}{$\mathrm{MLD}=134-140 \mathrm{~m}$} & 79 & 22.3 & $2.37 \pm 0.06$ & 79 & 0.29 & 1.18 \\
\hline & 100 & 21.9 & $2.16 \pm 0.08$ & 100 & n.a. & n.a. \\
\hline & 149 & 30.5 & 2.03 & 170 & 0.37 & $1.41 \pm 0.06$ \\
\hline & 199 & 63.2 & $1.48 \pm 0.00$ & 260 & 0.28 & $1.36 \pm 0.06$ \\
\hline & 300 & 86.0 & $1.41 \pm 0.09$ & 420 & 0.14 & $1.34 \pm 0.21$ \\
\hline & 398 & 87.6 & 1.58 & 749 & 0.13 & $1.32 \pm 0.10$ \\
\hline & 553 & 88.9 & $1.37 \pm 0.16$ & 1128 & 0.14 & $1.30 \pm 0.18$ \\
\hline & 704 & 90.1 & 1.53 & 1695 & 0.03 & $1.24 \pm 0.15$ \\
\hline & 1201 & 101.9 & 1.35 & 2488 & 0.11 & $1.42 \pm 0.20$ \\
\hline & 1601 & 109.5 & 1.47 & & & \\
\hline & 2001 & 121.7 & 1.30 & & & \\
\hline & 2551 & 131.2 & 1.13 & & & \\
\hline Large 6 & 3 & 4.0 & 2.47 & 3 & 0.13 & \\
\hline 8 March 2008 & 48 & 4.0 & 2.48 & 48 & 0.31 & $2.00 \pm 0.02 *$ \\
\hline $01.18^{\circ} \mathrm{E}-50.22^{\circ} \mathrm{S}$ & 98 & 5.1 & 2.47 & 98 & 0.32 & \\
\hline $\mathrm{MLD}=80-88$ & & & & & & \\
\hline Super 3 & 5 & 2.1 & $3.24 \pm 0.01$ & 5 & 0.13 & \\
\hline 6 March 2008 & 41 & 2.2 & 2.85 & 41 & 0.32 & $2.50 \pm 0.06^{*}$ \\
\hline $4.23^{\circ} \mathrm{E}-47.33^{\circ} \mathrm{S}$ & 79 & 2.2 & 2.36 & 79 & 0.06 & \\
\hline \multirow[t]{6}{*}{$M L D=82-88 \mathrm{~m}$} & 100 & 4.2 & $2.57 \pm 0.19$ & 100 & 0.10 & \\
\hline & 149 & 9.2 & 2.30 & 600 & 0.10 & $2.30 \pm 0.03$ \\
\hline & 200 & 10.4 & 2.42 & 1068 & 0.05 & $2.29 \pm 0.06$ \\
\hline & 401 & 25.3 & $1.93 \pm 0.35$ & & & \\
\hline & 600 & 1.67 & 1.67 & & & \\
\hline & 1002 & 1.43 & 1.43 & & & \\
\hline Super 2 & 10 & 0.6 & 3.24 & 70 & 0.04 & $2.03 \pm 0.18$ \\
\hline 27 February 2008 & 40 & 1.0 . & n.a. & & & \\
\hline \multirow{2}{*}{\multicolumn{7}{|c|}{$\begin{array}{l}8.56^{\circ} \mathrm{E}-42.28^{\circ} \mathrm{S} \\
\mathrm{MLD}=23-39 \mathrm{~m}\end{array}$}} \\
\hline & & & & & & \\
\hline Super 1 & 4 & 2.2 & $3.04 \pm 0.24$ & 4 & 0.08 & \\
\hline 21 February 2008 & 25 & 2.3 & $2.89 \pm 0.07$ & 25 & 0.28 & $1.30 \pm 0.10^{*}$ \\
\hline $13.10^{\circ} \mathrm{E}-36.45^{\circ} \mathrm{S}$ & 50 & n.a. & n.a. & 50 & 0.22 & \\
\hline$M L D=13-19 m$ & & & & & & \\
\hline
\end{tabular}

* Samples in the mixed layer have been merged for Si-isotopic analysis. 


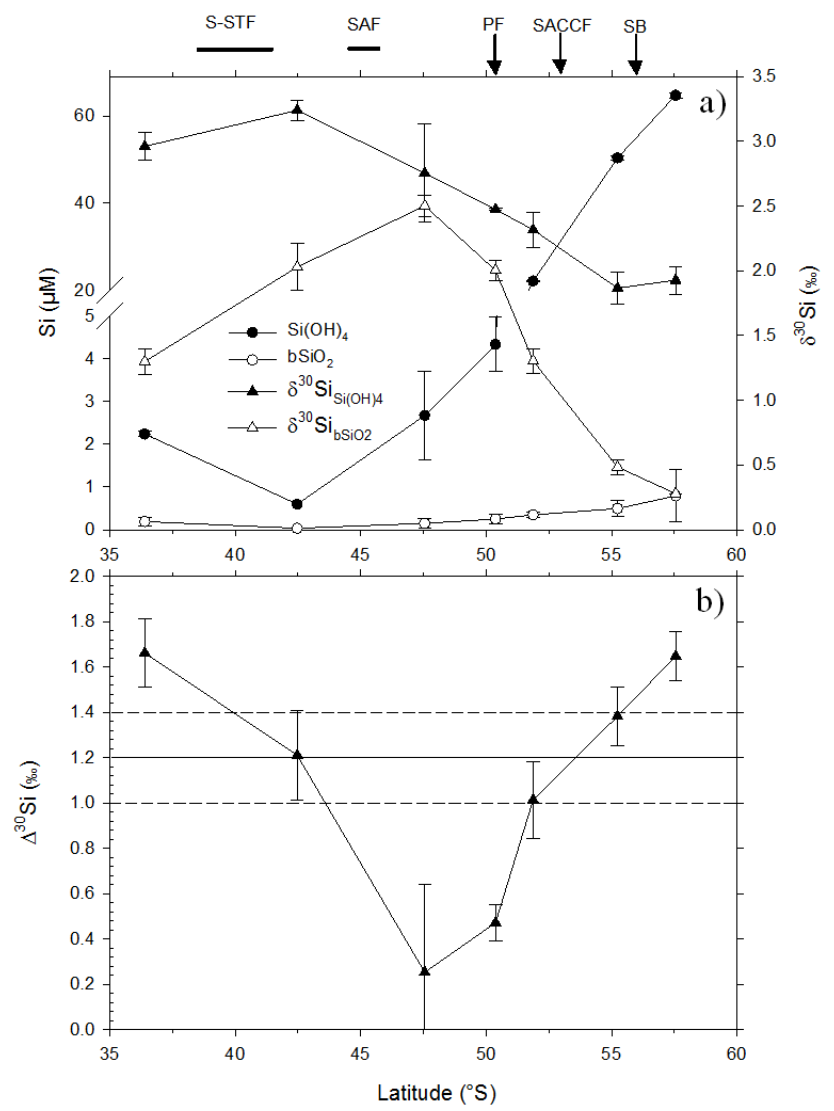

Fig. 2. (a) Latitudinal variation in the mixed layer (mean $\pm s d)$ for concentrations and isotopic composition. The dots represent the concentration and the triangles the isotopic compositions, respectively, black and white for $\mathrm{Si}(\mathrm{OH})_{4}$ and $\mathrm{bSiO}_{2}$. Panel (b) shows the latitudinal variation of apparent fractionation factor $\left(\Delta^{30} \mathrm{Si}=\right.$ $\delta^{30} \mathrm{Si}_{\mathrm{Si}(\mathrm{OH})_{4}}-\delta^{30} \mathrm{Si}_{\mathrm{bSiO}_{2}}$ ). The horizontal lines represent the compiled average ACC fractionation factor $\left(-{ }^{30} \varepsilon=1.2 \pm 0.2 \%\right.$ o given in Fripiat et al. (2011a). Arrows and lines represent the positions of the front at the time of sampling.

towards the surface (Table 1; see Fripiat et al., 2011b for a more complete discussion on water-column profiles of $\delta^{30} \mathrm{Si}_{\mathrm{Si}(\mathrm{OH})_{4}}$ ), similar to previous studies (e.g. Cardinal et al., 2005). While biogenic silica concentrations exhibit an inverse pattern (Fig. $4 \mathrm{a}, \mathrm{c}$ ), $\delta^{30} \mathrm{Si}_{\mathrm{bSiO}_{2}}$ remains constant with depth in the AZ and in the upper $\sim 1000 \mathrm{~m}$ of the northern WG and the PFZ (Fig. 4b, d). In the WG, $\delta^{30} \mathrm{Si}_{\mathrm{bSiO}}$ decreases just below the mixed layer, coinciding with a decrease in $\mathrm{bSiO}_{2}$ and $\delta^{30} \mathrm{Si}_{\mathrm{Si}(\mathrm{OH})_{4}}$, while below $1000 \mathrm{~m}$ $\delta^{30} \mathrm{Si}_{\mathrm{bSiO}}$ increases.

\section{Discussion}

Proxies can be influenced by multiple factors, and the sensitivity of a specific proxy to these factors likely changes in space and time. In the following sections, we discuss the processes controlling the origin of the isotopic composition
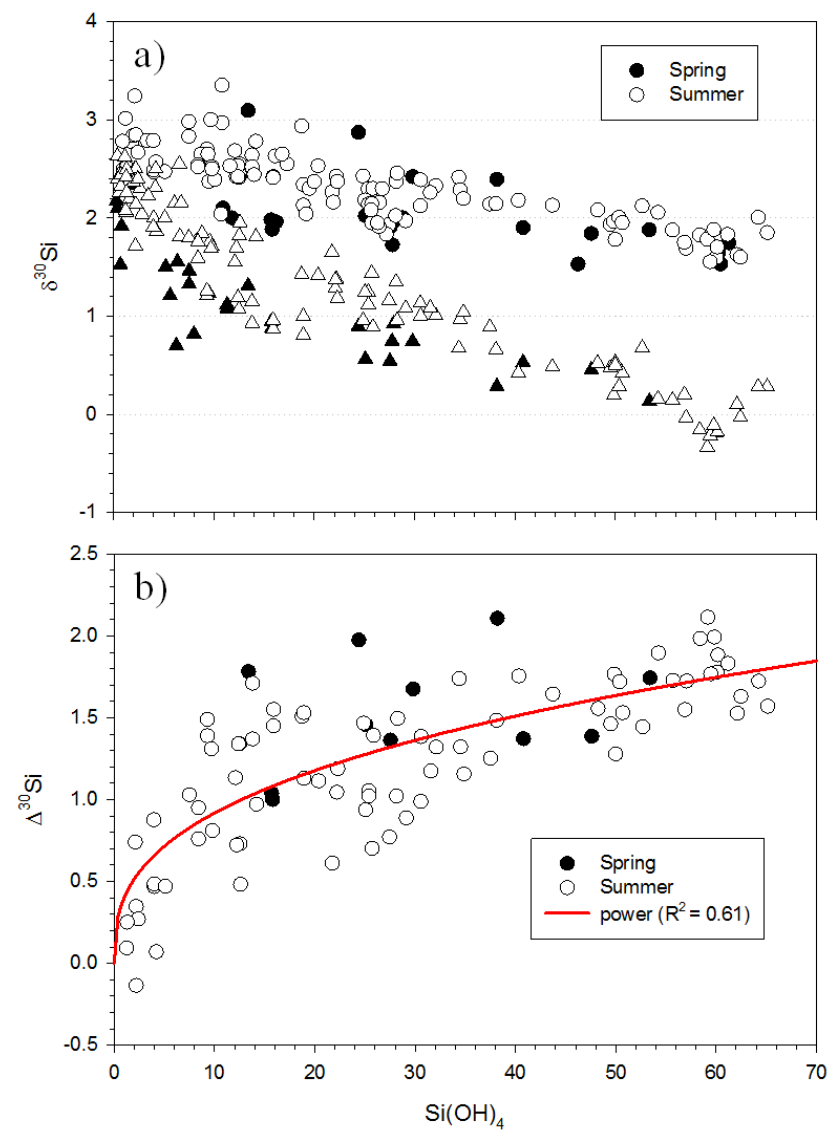

Fig. 3. (a) Mixed layer $\delta^{30} \mathrm{Si}$ (both for $\mathrm{Si}(\mathrm{OH})_{4}$ and $\mathrm{bSiO}_{2}$ ) vs. $\left[\mathrm{Si}(\mathrm{OH})_{4}\right]$ for the SIZ-WG, AZ, and PFZ. Triangles refer to isotopic composition of $\mathrm{bSiO}_{2}$ and circles to $\mathrm{Si}(\mathrm{OH})_{4}$. Filled symbols refer to spring data and open symbols to summer data. (b) Mixed layer $\Delta^{30} \mathrm{Si}$ vs. $\left[\mathrm{Si}(\mathrm{OH})_{4}\right]$ for the SIZ-WG, AZ, and PFZ (Varela et al., 2004; Cardinal et al., 2005, 2007; Fripiat et al., 2011a, b; Cavagna et al., 2011; this study). Filled symbols refer to spring data and open symbols to summer data. In (b), a non-linear regression (power function) fitting the data is shown $\left(R^{2}=0.61\right.$, p-value $\left.<0.01\right)$.

of biogenic silica in the mixed layer (Sect. 4.1) and subsequently the fate of the isotopic composition of biogenic silica across the water column (Sect. 4.2). The link between the isotopic composition and the relative silicic acid utilization in the surface waters will be investigated.

\subsection{Origin of the mixed layer biogenic silica isotopic composition}

Two models are commonly applied to describe Si-isotopic fractionation during Si-consumption by diatoms, directly linking the $\delta^{30} \mathrm{Si}$ to the relative utilisation of $\mathrm{Si}(\mathrm{OH})_{4}$. If a pool of silicic acid is consumed without resupply during the consumption process and with a constant fractionation factor $\left({ }^{30} \varepsilon\right)$, then the isotopic evolution of the remaining $\mathrm{Si}(\mathrm{OH})_{4}$, instantaneous $\mathrm{bSiO}_{2}$ (hereafter referred to with the superscript "inst"), and accumulated $\mathrm{bSiO}_{2}$ (hereafter referred to 

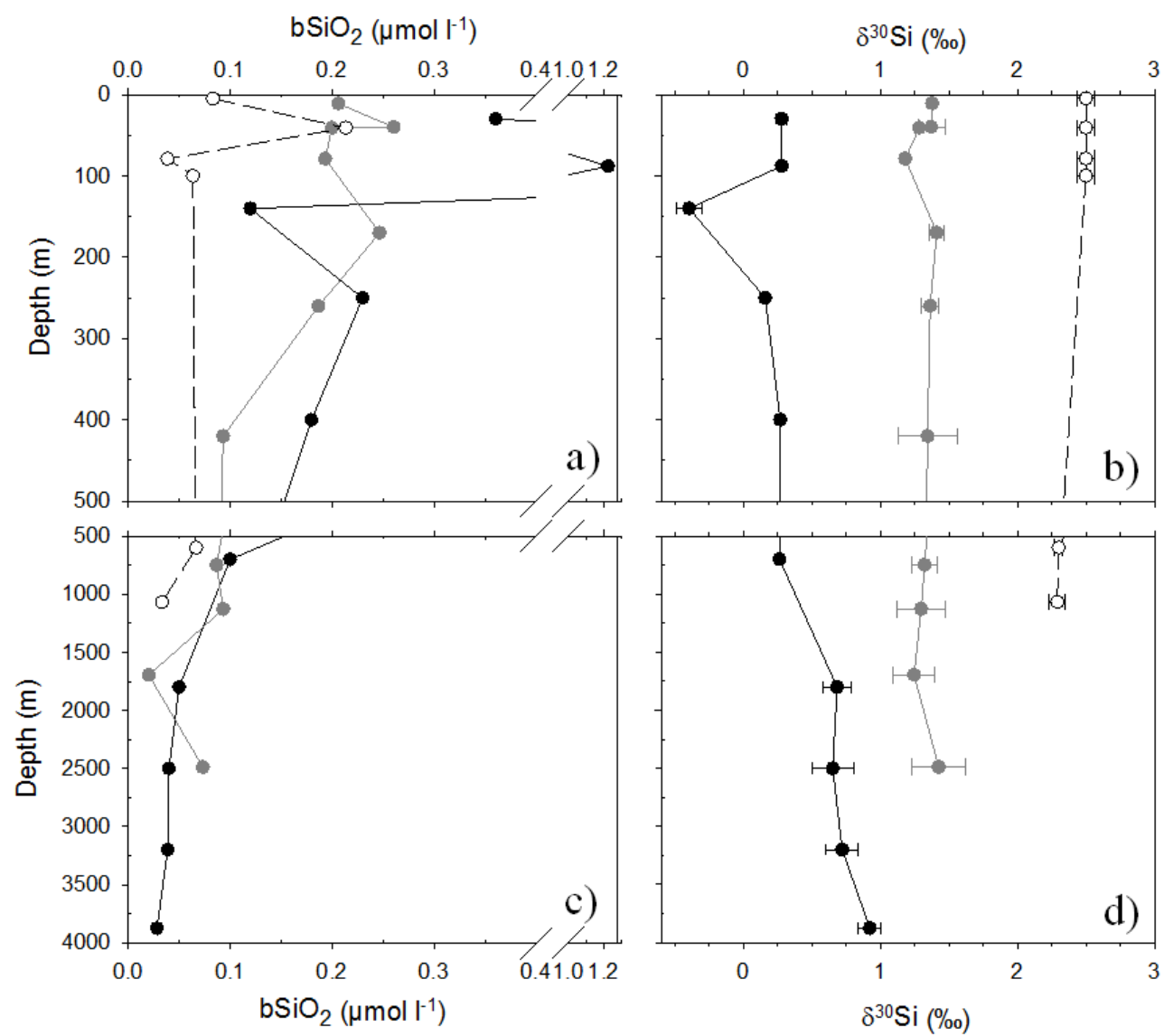

Fig. 4. Vertical profiles for the stations in the Weddell Gyre (filled black circles), the Antarctic Zone (filled gray circles), and the Polar Front Zone (empty black circles), respectively, super 5, super 4 and super 3. (a) and (c) bSiO 2 concentration profiles. (b) and (d) $\delta^{30} \mathrm{Si}$ profiles of $\mathrm{bSiO}_{2}$.

with the superscript "acc") should follow the Rayleigh fractionation equations (De La Rocha et al., 1997):

$\delta^{30} \mathrm{Si}_{\mathrm{Si}(\mathrm{OH})_{4[\mathrm{t}]}}=\delta^{30} \mathrm{Si}_{\mathrm{Si}(\mathrm{OH})_{4}[t 0]}+{ }^{30} \varepsilon \cdot \ln (f)$

$\delta^{30} \mathrm{Si}_{\mathrm{bSiO}_{2[t]}}^{\mathrm{Inst}}=\delta^{30} \mathrm{Si}_{\mathrm{Si}(\mathrm{OH})_{4}[t]}+{ }^{30} \varepsilon$

$\delta^{30} \mathrm{Si}_{\mathrm{bSiO}_{2[t]}}^{\mathrm{Acc}}=\delta^{30} \mathrm{Si}_{\mathrm{Si}(\mathrm{OH})_{4}[t 0]}-{ }^{30} \varepsilon \cdot \frac{f \cdot \ln (f)}{1-f}$

where $f$ is the $\left[\mathrm{Si}(\mathrm{OH})_{4}\right]_{[t]}:\left[\mathrm{Si}(\mathrm{OH})_{4}\right]_{[t 0]}$ ratio. The subscript " $[t]$ " is the sampling time and " $[t 0]$ " the initial time. Note that in such a system, the apparent fractionation factor $\left(\Delta^{30} \mathrm{Si}=\delta^{30} \mathrm{Si}_{\mathrm{Si}(\mathrm{OH})_{4}}-\delta^{30} \mathrm{Si}_{\mathrm{bSiO}_{2}}\right.$ ) is either constant (Eq. (2) for instantaneous $\mathrm{bSiO}_{2}$ ) or increases (Eq. (3) for accumulated $\mathrm{bSiO}_{2}$ ) with silicic acid consumption.

The alternative to this closed system is the open, flowthrough system, where the substrate is continuously supplied where the reaction continuously occurs at the same rate (also referred to as steady state system, Fry, 2006).

$$
\begin{aligned}
& \delta^{30} \mathrm{Si}_{\mathrm{Si}(\mathrm{OH})_{4}[t]}=\delta^{30} \mathrm{Si}_{\mathrm{Si}(\mathrm{OH})_{4}[t 0]}-{ }^{30} \varepsilon \cdot(1-f) \\
& \delta^{30} \mathrm{Si}_{\mathrm{bSi}}{ }_{2[t]}=\delta^{30} \mathrm{Si}_{\mathrm{Si}(\mathrm{OH})_{4}[t 0]}+{ }^{30} \varepsilon \cdot f=\delta^{30} \mathrm{Si}_{\mathrm{Si}(\mathrm{OH})_{4}[t]}+{ }^{30} \varepsilon
\end{aligned}
$$

The steady state system assumes equilibrium and does not represent a temporal evolution. Conceptually, for the Southern Ocean this poses a problem, since Si-depletion is observed in the mixed layer as a result of varying growth and export of diatoms (Brzezinski et al., 2001). Note that in such a system, $\Delta^{30} \mathrm{Si}$ is constant (Eq. 5) along with silicic acid consumption.

Neither of these models can explain the large variability that is observed in $\delta^{30} \mathrm{Si}_{\mathrm{bSiO}_{2}}$ values compared to $\delta^{30} \mathrm{Si}_{\mathrm{Si}(\mathrm{OH})_{4}}$ (Fig. 3a), and therefore the associated low and high $\Delta^{30} \mathrm{Si}$ (Fig. 3b). These model failures may result from the non-validity of one of the underlying model assumptions. We will investigate the impact of the following assumptions: (1) the fractionation factor is constant all along the seasonal $\mathrm{Si}(\mathrm{OH})_{4}$ depletion (Sect. 4.1.1), and (2) the seasonal expression of the different isotopic effects is under-resolved in the model equations (Sects. 4.1.2 and 4.1.3). 


\subsubsection{Variability in the fractionation factor}

The mean apparent fractionation factor $\left(\Delta^{30} \mathrm{Si}=\right.$ $\left.\delta^{30} \mathrm{Si}_{\mathrm{Si}(\mathrm{OH})_{4}}-\delta^{30} \mathrm{Si}_{\mathrm{bSiO}_{2}}\right)$ south of the Subantarctic Front is $1.3 \pm 0.5 \%$ o ( $n=90$; Fig. $3 b$ ). Assuming that there is no accumulation of biogenic silica in the mixed layer, $\Delta^{30} \mathrm{Si}$ should be equal, but with a opposite sign, to the fractionation factor associated with biogenic silica production ${ }^{30} \varepsilon$; Eqs. 2 and 5). The latter is not significantly different from the in vitro ${ }^{30} \varepsilon$ estimation with temperate diatom species $\left(-1.1 \pm 0.4 \%\right.$; De La Rocha et al., 1997), the in situ ${ }^{30} \varepsilon$ compilation in the ACC $(-1.2 \pm 0.2 \%$; Fripiat et al., 2011a), or the different ${ }^{30} \varepsilon$ estimations reported in other oceanic regions (De La Rocha et al., 2000; Reynolds et al., 2006; Beucher et al., 2008). Despite that these different estimations are roughly centered on the in vitro estimations from De La Rocha et al. $(1997 ;-1.1 \pm 0.4 \%$ ) , the large dispersion (from -0.4 to $-2.0 \%$ ) suggests that the constancy of the fractionation factor can be discussed.

In the Southern Ocean, a clear trend between $\Delta^{30} \mathrm{Si}$ and silicic acid concentration is observed in the mixed layer (Fig. 3b). If indeed $\Delta^{30} \mathrm{Si}$ can be taken as an estimate of $-{ }^{30} \varepsilon$, then such dataset can result from a causal link between silicic acid concentration and the extent of Si-isotopic fractionation. However, the physiological mechanisms leading to the fractionation of $\mathrm{Si}$-isotopes by diatoms are still poorly assessed and understood. Several mechanisms can induce a variation in ${ }^{30} \varepsilon$ : (1) an inter-specific variation, and an impact of (2) the Si-cellular metabolic balance and (3) the $\mathrm{bSiO}_{2}$ dissolution. In the following, these three points will be discussed:

1. Recently, Sutton et al. (2011) suggested an inter-specific variation in Southern Ocean diatoms based on in vitro incubations. Such observations are not in agreement with De La Rocha et al. (1997)'s hypothesis showing no inter-specific variation with temperate diatom species. Despite of being very hypothetical, different diatom species adapted to different silicic acid availability, together with different fractionation factors, could explain the observed relationship between $\Delta^{30} \mathrm{Si}$ and silicic acid concentration (Fig. 3b).

2. If the main Si-isotopic fractionation is occurring within the diatom cell (e.g. during the polymerization of biogenic silica), the isotopic fractionation will be more expressed when the efflux:influx ratio increases (Milligan et al., 2004), as expressed in the following equation:

${ }^{30} \varepsilon_{\text {net }}={ }^{30} \varepsilon_{\text {inf }}+\frac{\rho_{\text {eff }}}{\rho_{\text {inf }}} \cdot\left({ }^{30} \varepsilon_{\text {poly }}-{ }^{30} \varepsilon_{\text {eff }}\right)$

where the subscript "Inf" (=influx) is the transport rate across the plasmalemna from outside to inside the cell; "poly" (=polymerisation) the rate of frustule formation inside the silicon vesicle deposit (SDV); "Eff" (efflux) the transport rate across the plasmalemna from inside to outside the cell.

The efflux has never been measured in situ, precluding any comparison with oceanic data. It has been suggested to be a consequence of transient imbalances between uptake and polymerization caused by a level of transport that exceeds the capacity of intracellular silicon-binding component (Martin-Jézéquel et al., 2000; Thamatrakoln and Hildebrand, 2008). Average concentration of $\mathrm{Si}(\mathrm{OH})_{4}$ in most of the ocean's euphotic zone is less than $10 \mu \mathrm{mol} \mathrm{Si} 1^{-1}$ (Garcia et al., 2005). $\mathrm{Si}(\mathrm{OH})_{4}$ uptake by field assemblages would mostly be directly controlled by silicic acid transporters (SITs), which would minimize the associated costs of excess uptake and efflux (Thamatrakoln and Hildebrand, 2008). On the other side, our data are all from the Southern Ocean where high $\mathrm{Si}(\mathrm{OH})_{4}$ concentrations prevail. These concentrations are expected to be in a range favoring diffusion mediated uptake, incidentally increasing the probability of efflux to occur (Thamatrakoln and Hildebrand, 2008).

If (i) the isotopic fractionation associated with the polymerization is larger than the ones occuring during both influx and efflux, and (ii) the efflux:influx ratio is proportional to the silicic acid concentration, then the isotopic fractionation associated with biogenic silica production should increase together with silicic acid concentration (Eq. 6), as observed in Fig. 3 b.

It seems unlikely that (1) and (2) are sufficient to fully explain the observed trend in Fig. $3 \mathrm{~b}$ since the $\Delta^{30} \mathrm{Si}$ Front is approaching zero at low concentrations. Indeed, it would suggest that either some diatom species or diatoms growing in environmental conditions unfavorable to efflux, specifically low $\mathrm{Si}(\mathrm{OH})_{4}$ concentration (Thamatrakoln and Hildebrand, 2008), do not fractionate the silicon isotopes. For (2), it implies that the fractionation associated with influx is $0 \%$ o (Eq. 6). This is in disagreement with the observations in other oceanic regions or with in vitro incubations: (i) $\Delta^{30} \mathrm{Si}$ north of the Subantarctic Front is larger than 1\%o despite low silicic acid concentrations, (ii) an imprint from isotopic fractionation is clearly observed on the surface $\delta^{30} \mathrm{Si}_{\mathrm{Si}(\mathrm{OH})_{4}}$ distribution in every oceanic areas measured to date, including the ones where low silicic acid concentration prevails all year (De La Rocha et al., 2000; Cardinal et al., 2005; Reynolds et al., 2006; Beucher et al., 2008; de Souza, 2011; this study), and (iii) Milligan et al. (2004) with in vitro incubations measured an isotopic fractionation $\left({ }^{30} \varepsilon \approx-1.6 \%\right.$ o) which seemed not to be affected by the efflux:inlux ratio and requiring a significant isotopic fractionation during influx.

3. Demarest et al. (2009) report that during dissolution of biogenic silica, light $\mathrm{Si}$-isotopes are released preferentially with a fractionation factor $\left({ }^{30} \varepsilon_{\text {diss }}\right)$ estimated to be at $-0.55 \pm 0.05 \%$. This effect partly counteracts the 
fractionation occurring during $\mathrm{bSiO}_{2}$ production. By increasing the mixed layer $D: P$ ratio, the net fractionation $\left({ }^{30} \varepsilon_{\text {net }}\right)$ factor associated with net $\mathrm{bSiO}_{2}$ production $(=\operatorname{net} P$ ) would be dampened as follows (Demarest et al., 2009):

${ }^{30} \varepsilon_{\text {net }}={ }^{30} \varepsilon_{\text {upt }}+\frac{D}{P} \cdot{ }^{30} \varepsilon_{\text {diss }}$.

Brzezinski et al. (2003) observed a shift in the mode of functioning of the surface silicon cycle, from $\mathrm{bSiO}_{2}$ dissolution supporting a small fraction of gross $\mathrm{bSiO}_{2}$ production during diatom bloom to $\mathrm{bSiO}_{2}$ dissolution supporting the majority of gross $\mathrm{bSiO}_{2}$ production during non-bloom periods when silica production is low. Applying strictly the Eq. (7), such isotopic effect could explain at the maximum only $0.55 \%$ of the variation observed in Fig. $3 \mathrm{~b}$ (being $\approx 2 \%$ ).

To conclude this section, the seasonal and spatial variations of the fractionation factor are not sufficient to fully explain the observed trends between $\Delta^{30} \mathrm{Si}$ and silicic acid concentration (Fig. 3b). Additional processes are required. In the following (Sects. 4.1.2 and 4.1.3), the seasonal variation in the expression of the different isotopic effects (dissolution and mixing) will be discussed together with induced disequilibriums between biogenic silica and silicic acid. A box model based on conservation of Si mass and isotopic composition during the productive period for the mixed layer is implemented in Sect. 4.1.2. The different hypotheses are tested in the Sect. 4.1.3.

\subsubsection{Model description}

Figure $5 \mathrm{a}$ shows the model structure with the associated fluxes: $\mathrm{Si}(\mathrm{OH})_{4}$ supply, $\mathrm{bSiO}_{2}$ production, dissolution, and export. The box represents a $100 \mathrm{~m}$ deep mixed layer and has two compartments: the $\mathrm{Si}(\mathrm{OH})_{4}$ and $\mathrm{bSiO}_{2}$ pools. South of Africa, Faure et al. (2011) estimated a mean mixed layer depth of $\pm 100 \mathrm{~m}$ for the productive period across the ACC (including the AZ, PFZ, and SAZ), in agreement with our assumption. The accumulated exported $\mathrm{bSiO}_{2}$ is also simulated, to assess the effects of seasonal changes upon the isotopic composition of exported $\delta^{30} \mathrm{Si}_{\mathrm{bSiO}}$, i.e. the variable measured in paleoceanography. Here, the productive period is assumed to have a duration of 90 days, with the productive peak roughly centered in December, as shown by chl $a / \mathrm{POC}$ satellite data and modeling studies (Pondaven et al., 1998; Moore and Abbot, 2000; Allison et al., 2010). Across the BGH transect which took place in late summer 2008, mixed layer silicon properties can be considered as representative of final summer conditions. This is supported by Si-uptake in the mixed layer being in the lower range of published values, $0.02 \pm 0.03 \mu \mathrm{mol} \mathrm{Si} 1^{-1} \mathrm{~d}^{-1}$ (mean Si-uptake from ${ }^{30} \mathrm{Si}$ tracer incubations for the BGH transect, $n=27$ samples, each incubated as triplicates; Fripiat, 2010). This indicates that the end of the diatoms' growth period has been reached. The
PFZ station was chosen as a case study for this simulation as both (1) near complete Si-depletion (Fig. 2a) and (2) low $\Delta^{30} \mathrm{Si}$ are observed (Fig. 2b). The model initial conditions (i.e. before the start of the growth season) are set using the Si-characteristics of subsurface waters in the PFZ by Fripiat et al. (2011b; median for the halocline in the PFZ, see Table 2 for the initial and final conditions), argued here to represent the winter mixed layer (Tomczak and Godfrey, 2001).

The vertical supply of Si to the mixed layer is described either by a constant flux (zero order equation) or by 10 discrete mixing events (every 9 days) supplying an equal quantity of $\mathrm{Si}$ into the mixed layer. The gross uptake rate of $\mathrm{Si}$ (=gross $\mathrm{bSiO}_{2}$ production) during the growth period is described by a Michaelis-Menten saturation function:

$V_{\mathrm{Si}_{[t]}}=\frac{V_{\max } \cdot\left[\mathrm{Si}(\mathrm{OH})_{4}\right]}{k_{\mathrm{Si}}+\left[\mathrm{Si}(\mathrm{OH})_{4}\right]}$

where $V_{\mathrm{Si}}$ is the specific uptake rate $\left(\mathrm{d}^{-1}\right), V_{\max }\left(\mathrm{d}^{-1}\right)$ the maximum specific uptake rate, and $k_{\mathrm{Si}}\left(\mu \mathrm{mol} \mathrm{l}^{-1}\right)$ the $\mathrm{Si}(\mathrm{OH})_{4}$ concentration when $V_{\mathrm{Si}}=V_{\max } / 2$. In the ACC silicon uptake is well described using the Michaelis-Menten relationship (Pondaven et al., 1998, 2000). The integrated (mixed layer depth $=$ MLD) gross $\mathrm{bSiO}_{2}$ production $(P$; $\mathrm{mmol} \mathrm{m} \mathrm{m}^{-2} \mathrm{~d}^{-1}$ ) is described as follows:

$P=\int_{0}^{\mathrm{MLD}} V_{\mathrm{Si}[t]} \cdot\left[\mathrm{bSiO}_{2}^{\mathrm{ML}}\right]_{[t]} \cdot \mathrm{d} z$.

The "ML" superscript indicates mixed layer biogenic silica (being the initial $\mathrm{bSiO}_{2}+$ net $\mathrm{bSiO}_{2}$ production, at each time step), which is a mixture of detrital and living diatom cells (Krause et al., 2010). The $\mathrm{bSiO}_{2}$ export $\left(=E, \mathrm{mmol} \mathrm{m}^{-2}\right.$ $\mathrm{d}^{-1}$ ) is described by a first order equation (first order constant $=k_{\text {export }}$ ):

$E=\int_{0}^{\mathrm{MLD}} k_{\text {export }} \cdot\left[\mathrm{bSiO}_{2}^{\mathrm{ML}}\right]_{[t]} \cdot \mathrm{d} z$.

The $\mathrm{bSiO}_{2}$ dissolution:production $(D: P)$ ratio is assumed to increase linearly (from 0.0 to 1.0 over the expected range Brzezinski et al., 2003; Fig. 5d):

$\frac{d\left(\frac{D}{P}\right)}{\mathrm{d} t}=\frac{1}{N_{\text {season }}}$

where $N$ is the number of days. The model could be oversimplified as in the ACC, $D: P$ ratios exceeding 1 have already been documented at the end of summer (Beucher et al., 2004; Fripiat et al., 2011c). This has been explained by an accumulation of detrital diatom cells in the mixed layer after a productive period.

The fractionation factor associated with net $\mathrm{bSiO}_{2}$ production is determined following equation 7 where ${ }^{30} \varepsilon_{\text {upt }}$ has 


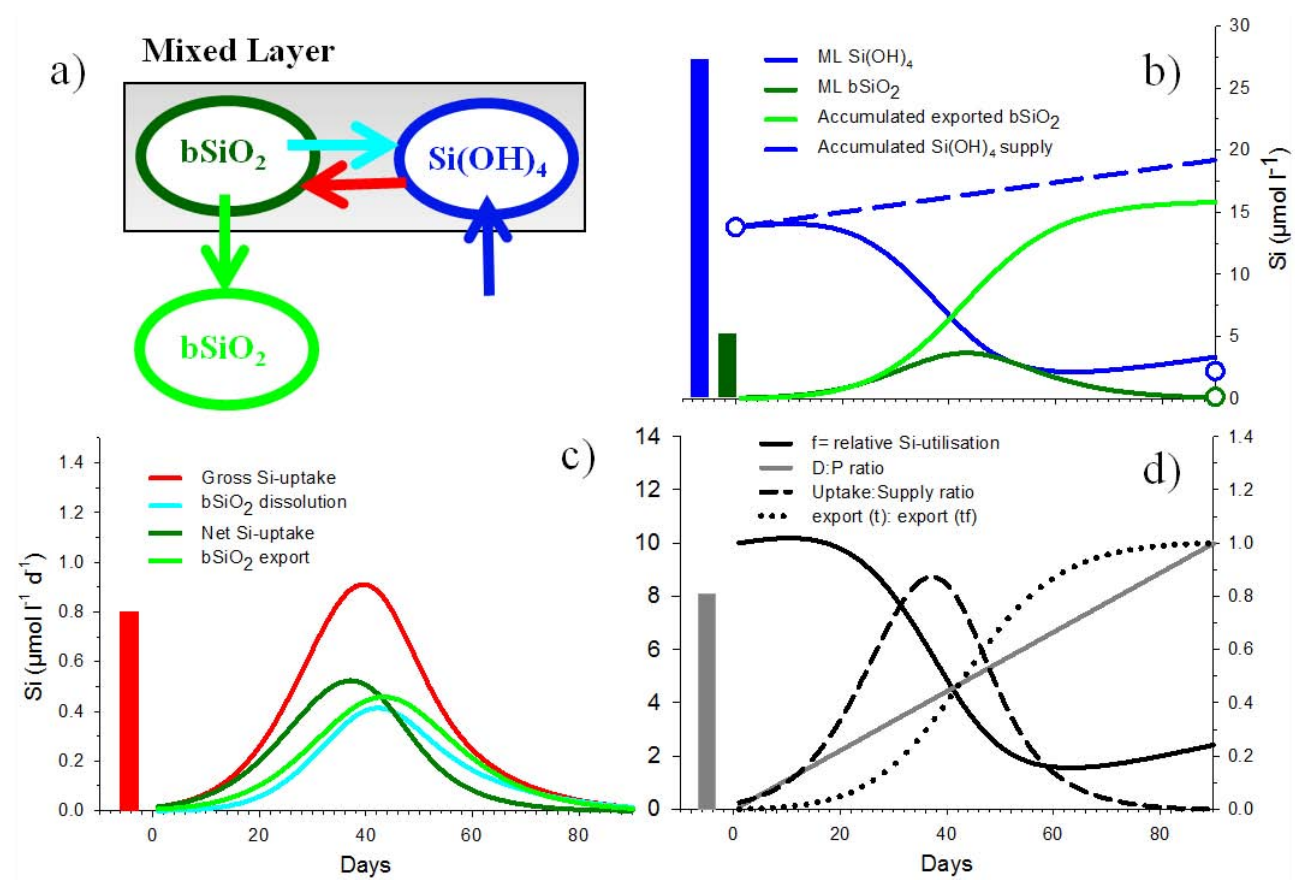

Fig. 5. (a) Schematic representation of the box model (=100 $\mathrm{m}$ deep mixed layer). Round boxes represent pools of silicic acid in the mixed layer (blue), biogenic silica in the mixed layer (dark green), and accumulated exported biogenic silica below the mixed layer (light green). Arrows stand for processes exchanging $\mathrm{Si}$ between the pools: gross $\mathrm{Si}$-uptake (red arrow), $\mathrm{bSiO}_{2}$ dissolution (cyan arrow), bSiO 2 export (green arrow), and vertical $\mathrm{Si}(\mathrm{OH})_{4}$ supply (blue arrow). (b, c, d) Model outputs for the PFZ simulation. Panel (b) simulated concentrations of $\mathrm{Si}(\mathrm{OH})_{4}$ and $\mathrm{bSiO}_{2}$ in the mixed layer, accumulated exported $\mathrm{bSiO}_{2}$, and accumulated Si-supply to the mixed layer. The initial and final estimations are indicated using empty dots with the corresponding colors (Table 2). Panel (c) simulated gross $\mathrm{Si}_{-}$-uptake, bSiO $\mathrm{O}_{2}$ dissolution, net Si-uptake, and $\mathrm{bSiO}_{2}$ export. (d) Simulated Si-uptake:supply ratio (left y-axis), relative $\mathrm{Si}(\mathrm{OH})_{4}$ utilization (right y-axis), export(t):export(tf) ratio (right y-axis) and $D: P$ ratio (right y-axis). $V_{\max }=0.41, K_{\mathrm{Si}}=4 \mu \mathrm{mol} 1^{-1}, k_{\text {export }}=0.13$, and subsurface $\mathrm{Si}(\mathrm{OH})_{4}$ (right y-axis) supply $=540 \mathrm{mmol} \mathrm{m}{ }^{-2}$. Brzezinski et al. (2001) is the only time series across the whole productive period describing the silicon biogeochemical dynamics in the Polar Front Zone in the Pacific Sector (PFZ between $61^{\circ} \mathrm{S}$ and $52^{\circ} \mathrm{S}$ ). The vertical bars in the (a), (b), and (c) represent the range for silicic acid and biogenic silica concentrations (respectively the blue and green vertical bars in $\mathbf{b}$ ), the gross Si-uptake (red vertical bar in c), and the $D: P$ ratio (gray vertical bar in $\mathbf{d}$ ).

been compiled for the ACC at $-1.2 \pm 0.2 \%$ in Fripiat et al. (2011a) and ${ }^{30} \varepsilon_{\text {diss }}$ has been measured experimentally at $-0.55 \pm 0.05 \%$ oy Demarest et al. (2009). Assuming a $D: P$ ratio evolution as described in Eq. (7), the ${ }^{30} \varepsilon_{\text {net }}$ at the beginning of the productive period will be equal to the ${ }^{30} \varepsilon_{\text {upt }}$ $(-1.2 \% o)$ and decrease to $-0.65 \% 0\left({ }^{30} \varepsilon_{\text {upt }}-{ }^{30} \varepsilon_{\text {diss }}\right)$ at the end, in agreement with Eq. (11). In the following discussion, model results with and without an isotopic fractionation during $\mathrm{bSiO}_{2}$ dissolution will be compared. Given the lack of information on the role Si-efflux on isotopic fractionation, we decided to not include Eq. (6) in this model.

Using the above parameters and assuming the silicic acid pool is homogeneous and is fed with silicic acid of constant $\delta^{30} \mathrm{Si}$ composition, the seasonal evolution can be described as follows:

$$
\begin{aligned}
& \frac{\mathrm{d}\left(m_{\mathrm{Si}(\mathrm{OH})_{4}}\right)}{\mathrm{d} t}=F_{\text {supply }}+\left(\frac{D}{P}_{[t]}-1\right) \cdot P_{[t]}=F_{\text {supply }}-\operatorname{net} P_{[t]} \\
& m_{\mathrm{Si}(\mathrm{OH})_{4}} \cdot \frac{\mathrm{d}\left(\delta^{30} \mathrm{Si}_{\mathrm{Si}(\mathrm{OH})_{4}}\right)}{\mathrm{d} t}=F_{\text {supply }} \cdot \delta^{30} \mathrm{Si}_{\text {supply }}-{ }^{30} \varepsilon_{[t]} \cdot \operatorname{net} P_{[t]}
\end{aligned}
$$

where $m$ is the molar quantity of silicon $\left(\mathrm{mmol} \mathrm{m}^{-2}\right)$ and $F_{\text {supply }}$ the $\mathrm{Si}(\mathrm{OH})_{4}$ supply $\left(\mathrm{mmol} \mathrm{m}^{-2} \mathrm{~d}^{-1}\right)$.

The biogenic silica pools are described as follows:

$$
\begin{aligned}
& \frac{\mathrm{d}\left(m_{\mathrm{bSiO}}^{\mathrm{ML}}\right)}{\mathrm{d} t}=\operatorname{net} P_{[t]}-E_{[t]} \\
& m_{\mathrm{bSiO}}^{\mathrm{ML}} \cdot \frac{\mathrm{d}\left(\delta^{30} \mathrm{Si}_{\mathrm{bSiO}_{2}}{ }^{\mathrm{ML}}\right)}{\mathrm{d} t}=\operatorname{net} P_{[t]} \\
& \quad \cdot\left(\delta^{30} \mathrm{Si}_{\mathrm{Si}(\mathrm{OH})_{4[t]}}+{ }^{30} \varepsilon_{[t]}\right)-E_{[t]} \cdot \delta^{30} \mathrm{Si}_{\mathrm{bSiO}_{2[t]}}^{\mathrm{ML}}
\end{aligned}
$$

$$
\frac{\mathrm{d}\left(m_{\mathrm{b}_{\mathrm{SiO} 2}}^{\text {export }}\right)}{\mathrm{d} t}=E_{[t]}
$$

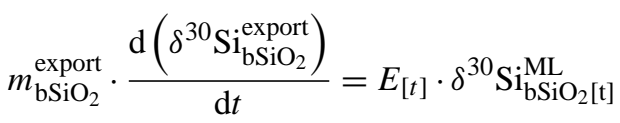



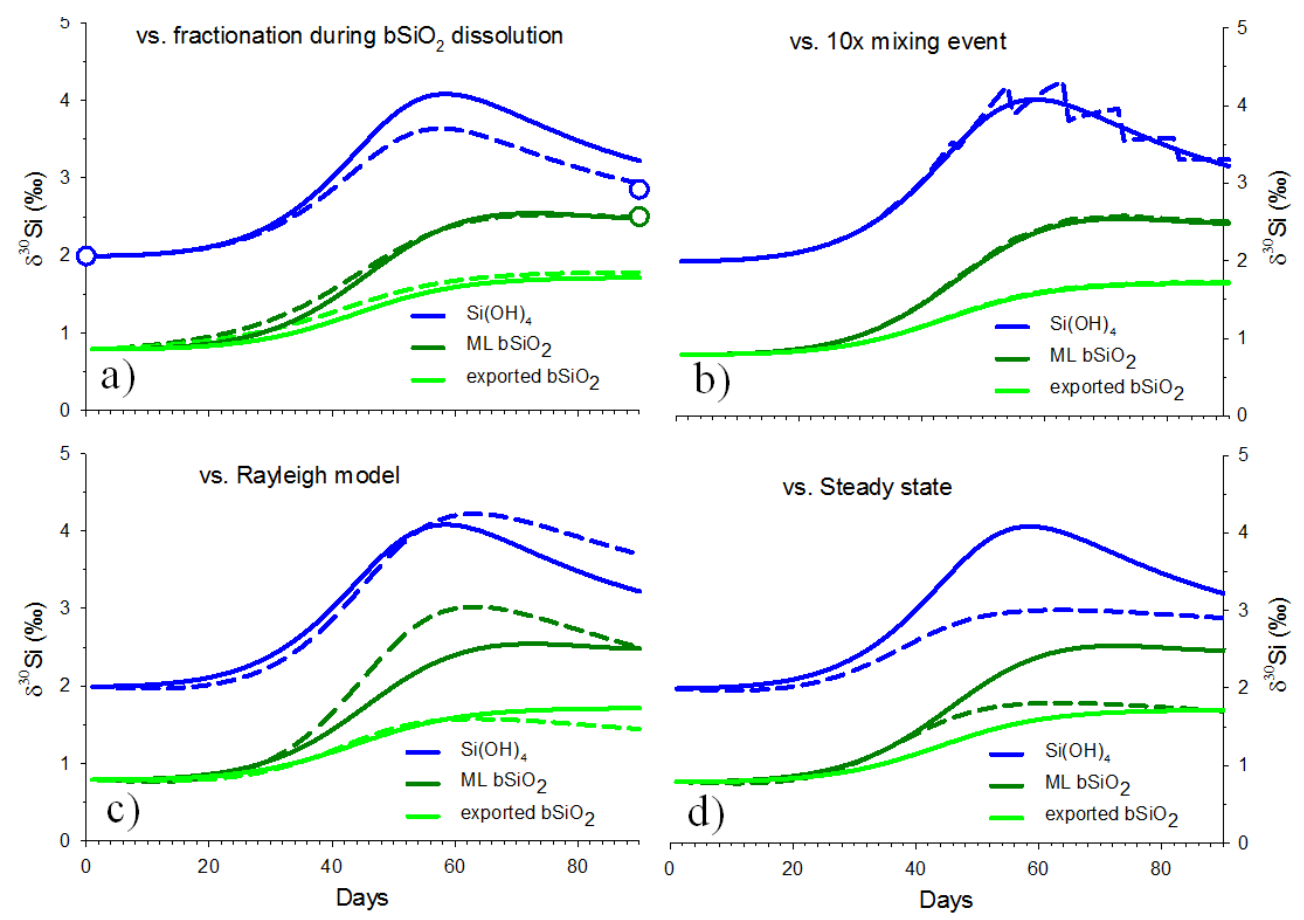

Fig. 6. Model outputs for the case study station in the PFZ. Panel (a) simulated $\delta^{30} \mathrm{Si}$ values for $\mathrm{Si}(\mathrm{OH})_{4}, \mathrm{ML}^{\mathrm{bSiO}}{ }_{2}, \mathrm{exported} \mathrm{bSiO}_{2}$ without (full lines) and with (dashed lines) $\mathrm{bSiO}_{2}$ dissolution isotopic fractionation $\left({ }^{30} \varepsilon=-0.55 \%\right.$ ). The initial and final estimations are indicated using empty dots with the corresponding colors (Table 2). Panel (b) simulated $\delta^{30} \mathrm{Si}$ values for $\mathrm{Si}(\mathrm{OH})_{4}, \mathrm{ML}^{\mathrm{bSiO}} 2, \mathrm{exported} \mathrm{bSiO}_{2}$ with continuous Si-supply (full lines) and 10 mixing events (dashed lines). (c) Comparison between the simulated $\delta^{30} \mathrm{Si}$ values (full lines) and Rayleigh model outputs (dashed line). For the Rayleigh model, $\mathrm{ML} \mathrm{bSiO}_{2}$ is the instantaneous product (sensu Rayleigh) and exported bSiO 2 the accumulated product (sensu Rayleigh). (d) Comparison between the simulated $\delta^{30} \mathrm{Si}$ values (full lines) and the Steady State model outputs (dashed lines).

Superscript "export" is the biogenic silica exported out of the mixed layer assuming that the exported fraction of biogenic silica has an isotopic composition similar to the one in the mixed layer. This could be an oversimplification since Krause et al. (2010) suggested that for the Equatorial Pacific exported biogenic silica can be composed of mainly detrital diatom cells.

Small errors arise for both mixing and fractionation when the $\delta$ notation is used instead of isotopic ratios. However, for $\delta$ values close to 0 , as is the case for Si isotopic system, these sources of errors are negligible (Fry, 2006). The aim here is to assess, with the current knowledge of the Sibiogeochemical dynamic, how the seasonal variability of the different isotopic effects potentially affects the mass and isotopic balances. This is of crucial importance for palaeoceanographic reconstructions of past ocean conditions. This approach should not be taken as an attempt to quantify fluxes (uptake, dissolution, export, and $\mathrm{Si}(\mathrm{OH})_{4}$ supply) or to constrain the complexity of the seasonal silicon cycle.

\subsubsection{Model outputs}

With the current knowledge of Si-biogeochemical dynamic in the Southern Ocean, the model seems to adequately repro- duce the seasonal evolution of silicic acid and biogenic silica concentrations in the PFZ mixed layer (Fig. 5; Brzezinski et al., 2001; Quéguiner and Brzezinski, 2002). The integrated Si-uptake of $1.6 \mathrm{~mol} \mathrm{Si} \mathrm{m}^{-2} \mathrm{yr}^{-1}$ fits relatively well with the mean expected values in the Polar Front Zone, $1.2 \mathrm{~mol} \mathrm{Si}$ $\mathrm{m}^{-2} \mathrm{yr}^{-1}$ (Fripiat et al., 2011c).

The simulated isotopic trends for $\delta^{30} \mathrm{Si}_{\mathrm{bSiO}_{2}}$ differ from the $\delta^{30} \mathrm{Si}_{\mathrm{Si}(\mathrm{OH})_{4}}$ trends, especially at the end of the productive period (Fig. 6a). In the PFZ the Si uptake:supply ratio is high at the beginning of the growth period, and, consequently, the $\delta^{30} \mathrm{Si}_{\mathrm{Si}(\mathrm{OH})_{4}}$ and $\delta^{30} \mathrm{Si}_{\mathrm{bSiO}_{2}}$ evolutions roughly follow a Rayleigh distillation (Figs. 5d and 6c). Note that the steady-state model is unable to reproduce the measured $\mathrm{ML} \delta^{30} \mathrm{Si}_{\mathrm{bSiO}_{2}}$ value and is in disagreement with the present simulation (Fig. 6d). Once the silicic acid concentration has reached a level that limits Si-uptake (Eq. 8), the Si uptake:supply ratio decreases and the supply by vertical mixing of lighter $\mathrm{Si}$ isotopic signatures into the $\mathrm{Si}$-depleted mixed layer decreases the ${ }^{30} \mathrm{Si}_{\mathrm{Si}(\mathrm{OH})_{4}}$ (Figs. 5d and 6). The $\delta^{30} \mathrm{Si}_{\mathrm{bSiO}_{2}}$ is affected differently, since both new and preceding diatom generations set the ML $\delta^{30} \mathrm{Si}_{\mathrm{bSiO}_{2}}$ (Eq. 14), especially at the end of the productive period when $\mathrm{bSiO}_{2}$ production is low. Such process decreases the $\Delta^{30} \mathrm{Si}$ and is consistent with our observations (Figs. 2b, 3b, and 7a). The 

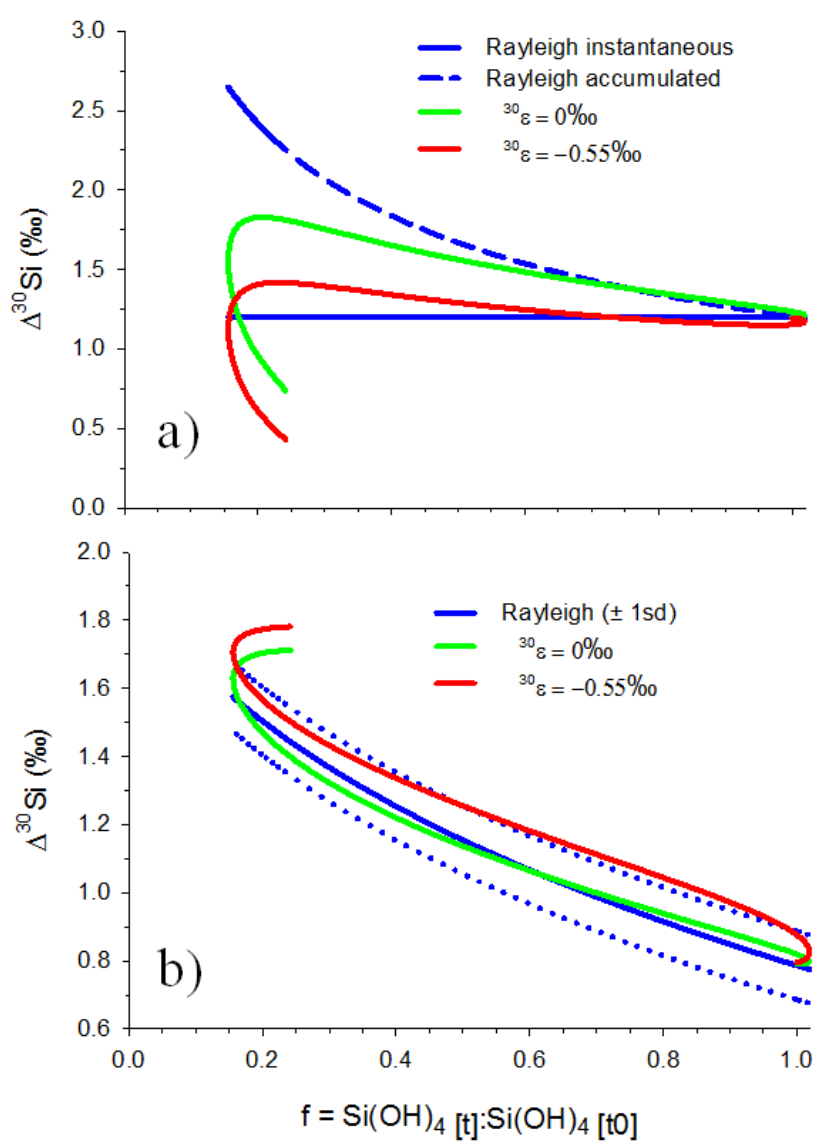

Fig. 7. (a) Simulated $\Delta^{30} \mathrm{Si} \quad\left(=\delta^{30} \mathrm{Si}_{\mathrm{Si}(\mathrm{OH})_{4}}-\right.$ mixed layer $\left.\delta^{30} \mathrm{Si}_{\mathrm{bSiO}_{2}}\right)$ vs. relative $\mathrm{Si}$-utilisation in the mixed layer $\left(=\left[\mathrm{Si}(\mathrm{OH})_{4}\right]_{(t)}:\left[\mathrm{Si}(\mathrm{OH})_{4}\right]_{(t 0)}\right)$ without (green line) and with (red line) an isotopic fractionation during $\mathrm{bSiO}_{2}$ dissolution. The isotopic difference between the Rayleigh $\delta^{30} \mathrm{Si}_{\mathrm{Si}(\mathrm{OH})_{4}}$ and either Rayleigh instantaneous $\delta^{30} \mathrm{Si}_{\mathrm{bSiO}_{2}}$ (full blue line) or Rayleigh accumulated $\delta^{30} \mathrm{Si}_{\mathrm{bSiO}_{2}}$ (dashed blue line) are also shown. (b) Simulated relationship between accumulated exported $\delta^{30} \mathrm{Si}_{\mathrm{bSiO}_{2}}$ and relative $\mathrm{Si}$-utilization in the mixed layer without (green line) and with (red line) an isotopic fractionation during $\mathrm{bSiO}_{2}$ dissolution. The relationship with the Rayleigh accumulated $\delta^{30} \mathrm{Si}_{\mathrm{bSiO}_{2}}$ (full blue line; 1 standard deviation = dashed blue lines) is also shown to compare.

exported $\mathrm{bSiO}_{2}$ out of the mixed layer fits with an accumulation product (sensu Rayleigh; Fig. 6c). This is seen from (1) Fig. $5 \mathrm{~d}$ showing that $\approx 85 \%$ of the export of biogenic silica occurs before the decreasing trend in $\delta^{30} \mathrm{Si}_{\mathrm{Si}(\mathrm{OH})_{4}}$ and, incidentally, the exported $\delta^{30} \mathrm{Si}_{\mathrm{bSiO}}$ is not significantly affected by processes occurring at the end of the productive period when the Si uptake:supply ratio is low; (2) Fig. 7b showing the relationships (non-significantly different) between the simulated exported $\delta^{30} \mathrm{Si}_{\mathrm{bSiO}_{2}}$ and the accumulated biogenic silica (sensu Rayleigh) with relative silicon utilisation $(=f)$. Note that this simulation is already sufficient to explain partly the measured range in the $\Delta^{30} \mathrm{Si}$ (Figs. 3 and $7 \mathrm{a}$ ).
Impact of isotopic fractionation during dissolution - by adding the isotopic fractionation of $\mathrm{bSiO}_{2}$ dissolution (Demarest et al., 2009), the $\delta^{30} \mathrm{Si}_{\mathrm{Si}(\mathrm{OH})_{4}}$ gets slightly lighter and the $\delta^{30} \mathrm{Si}_{\mathrm{bSiO}_{2}}$ slightly heavier (Fig. 6a), relative to the model runs without such fractionation, throughout the productive period, in agreement with a decrease in the net fractionation extent (Eq. 7). This process together with the low Siuptake:supply ratio could explain the lowest $\Delta^{30} \mathrm{Si}$ measured at the end of the productive period (Fig. 7a). The latter could bias the relationship between the exported $\delta^{30} \mathrm{Si}_{\mathrm{bSiO}_{2}}$ and the relative silicic acid utilization $(=f)$. Nevertheless, such bias is lying within isotopic analytical precision (Fig. 7b) and therefore should not impact on the use and interpretation of this proxy in palaeoceanography. Furthermore, the isotopic effect of dissolution could have been over-expressed in this simulation since the $D: P$ ratio at the $\mathrm{bSiO}_{2}$ productive peak was already high (0.4) in comparison with published values, which are close to 0.1 (Brzezinski et al., 2003).

Impact of mixing events - by switching from a continuous supply to a pulsed supply mode, consisting of 10 consecutive instantaneous mixing events, the simulation is scattered around the continuous supply with no effect on biogenic silica isotopic composition (Fig. 6b). Moreover, in reality, mixing is probably spatially heterogeneous and lateral mixing should smooth the trends toward the mean continuous supply.

As a comparison, similar simulations have been carried out in the SAZ, an area characterized, in contrast to PFZ, by a lower vertical silicic acid gradient, and in the AZ characterized by an incomplete $\mathrm{Si}$ depletion of the summer mixed layer (Fripiat et al., 2011b). The model's initial conditions (i.e. before the start of the growth season) are set using the $\mathrm{Si}$ characteristic of subsurface waters, respectively, in the SAZ and AZ by Fripiat et al. (2011b; median for the thermocline and the halocline, see Table 2 for initial and final conditions), assumed here to represent the winter mixed layer in both areas (Tomczak and Godfrey, 2001). In order to agree as much as possible with the PFZ simulation, the Si-supply over $\mathrm{bSiO}_{2}$ production ratio has been fit at $\sim 0.3$ and the $D: P$ ratio at the productive peak at $\sim 0.4$. For the same relative vertical mixing, the vertical supply of light Si-isotopes at the end of summer (low Si-uptake:supply ratio) is not sufficient to lower the mixed layer $\delta^{30} \mathrm{Si}_{\mathrm{Si}(\mathrm{OH})_{4}}$ (Fig. 8). Therefore, it enables us to explain low $\Delta^{30} \mathrm{Si}$ values observed only in the PFZ and PF (Fig. $2 b$ ), both characterized by heavily Si-depleted mixed layer together with a large vertical silicic acid gradient.

The relationship between the accumulated exported $\delta^{30} \mathrm{Si}_{\mathrm{bSiO}}$ and relative Si-utilization was not significantly different from the simulation with the accumulated product (sensu Rayleigh; Fig. 7b), both with and without isotopic fractionation during $\mathrm{bSiO}_{2}$ dissolution. Therefore, for reconstructing past $\mathrm{Si}(\mathrm{OH})_{4}$ utilisation in the ACC surface waters from sedimentary $\delta^{30} \mathrm{Si}_{\mathrm{bSiO}_{2}}$ data, our results indicate that a Rayleigh $\mathrm{bSiO}_{2}$ accumulated product model is more appropriate than a steady-state model. This mainly results from the 
Table 2. Initial and final conditions, $\mathrm{Si}(\mathrm{OH})_{4}$ and $\mathrm{bSiO}_{2}$ concentrations and isotopic compositions, for the model run (AZ, PFZ, and $\mathrm{SAZ}$ ). Due to their asymmetric distribution, the median value has been chosen to be representative of the central values (Fripiat et al., 2011b). The initial conditions are the subsurface water in each zone: the halocline in both the AZ and PFZ, and the thermocline in the SAZ. The final conditions are the corresponding mixed layer: respectively, super stations 2, 3, and 4 for the SAZ, PFZ, and AZ (Fig. 1).

\begin{tabular}{|c|c|c|c|c|c|c|}
\hline \multirow[t]{2}{*}{ Zones } & \multicolumn{2}{|c|}{ Initial conditions } & \multicolumn{4}{|c|}{ Final conditions } \\
\hline & $\begin{array}{c}{\left[\mathrm{Si}(\mathrm{OH})_{4}\right]} \\
\mu \mathrm{mol} 1^{-1}\end{array}$ & $\begin{array}{r}\delta^{30} \mathrm{Si}_{\mathrm{Si}(\mathrm{OH}) 4} \\
\% \circ\end{array}$ & $\begin{array}{l}{\left[\mathrm{Si}(\mathrm{OH})_{4}\right]} \\
\mu \mathrm{mol} 1^{-1}\end{array}$ & $\begin{array}{r}\delta^{30} \mathrm{Si} \\
{ }_{\% o} \mathrm{Si}(\mathrm{OH}) 4\end{array}$ & $\begin{array}{r}\mathrm{bSiO}_{2} \\
\mu \mathrm{mol} 1^{-1}\end{array}$ & $\begin{array}{r}\delta^{30} \mathrm{Si}_{\mathrm{bSiO} 2} \\
\% \circ\end{array}$ \\
\hline Antarctic Zone & 58.9 & 1.57 & 22.2 & 2.37 & 0.30 & 1.33 \\
\hline Polar Front Zone & 13.8 & 1.99 & 2.2 & 2.71 & 0.13 & 2.50 \\
\hline Subantarctic Zone & 3.1 & 1.96 & 0.8 & 3.24 & 0.04 & 2.03 \\
\hline
\end{tabular}

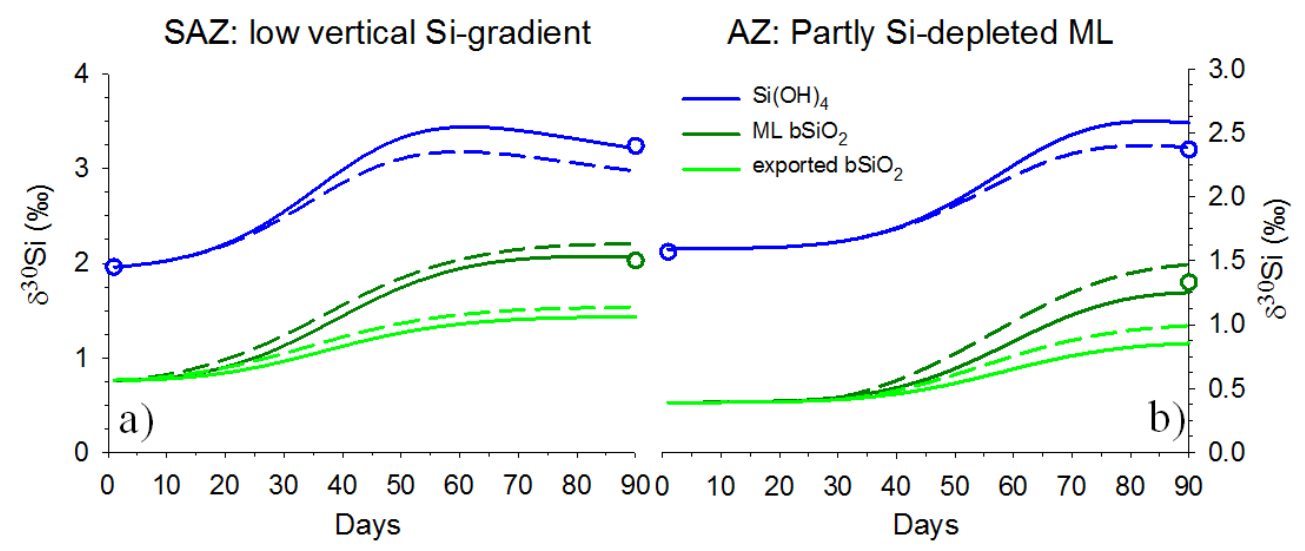

Fig. 8. Model outputs for the $\mathrm{SAZ}$ (a) and $\mathrm{AZ}(\mathbf{b})$. Simulated $\delta^{30} \mathrm{Si}$ values for $\mathrm{Si}(\mathrm{OH})_{4}, \mathrm{ML} \mathrm{bSiO}_{2}$, exported bSiO $\mathrm{b}_{2}$ without (full lines) and with (dashed lines) $\mathrm{bSiO}_{2}$ dissolution isotopic fractionation ${ }^{30} \varepsilon=-0.55 \%$ ). The initial and final estimations are indicated by empty dots with the corresponding colors (Table 2). Respectively, for the SAZ and AZ: $V_{\max }=0.40$ and $0.31 \mathrm{~d}^{-1}, K_{\mathrm{Si}}=2$ and $10 \mu \mathrm{mol} 1^{-1}$, $k_{\text {export }}=0.11$ and $0.13 \mathrm{~d}^{-1}, \mathrm{Si}(\mathrm{OH})_{4}$ supply $=77$ and $1170 \mathrm{mmol} \mathrm{m}^{-2}$, and net $\mathrm{bSiO}_{2}$ production $=275$ and $4149 \mathrm{mmol} \mathrm{m}^{-2}$.

high silicic acid supply:consumption ratio during the main part of the $\mathrm{bSiO}_{2}$ production period. Consequently, mixing has no significant impact on the exported $\delta^{30} \mathrm{Si}_{\mathrm{bSiO}_{2}}$.

\subsection{Fate of biogenic silica isotopic composition across the water column}

The fate of biogenic silica $\delta^{30} \mathrm{Si}$ through the water column is of prime importance to link the sedimentary $\delta^{30} \mathrm{Si}$ to the surface environmental conditions in which they were generated. Dissolution during settling could affect the $\delta^{30} \mathrm{Si}_{\mathrm{bSiO}}$ distributions by shifting the preserved material toward more positive values (Demarest et al., 2009). By analysing the $\delta^{30} \mathrm{Si}$ of sinking biogenic silica (two sediment traps in the AZ at 1031 and $2182 \mathrm{~m}$ in the Pacific sector; Varela et al., 2004) a remarkable agreement with surface values was observed. This is further confirmed by the present study which present the first whole water column profiles of suspended biogenic silica ${ }^{30} \mathrm{Si}$ signatures (Fig. 4). The isotopic composition of subsurface suspended biogenic silica generally reflects that of the mixed layer. It thus seems that dissolution does not significantly affect the $\delta^{30} \mathrm{Si}$ signal of exported $\mathrm{bSiO}_{2}$. However, there are two notable exceptions:
1. In the WG, the $\delta^{30} \mathrm{Si}_{\mathrm{bSiO}}$ is becoming heavier by 0.4 to $0.8 \%$ below $1800 \mathrm{~m}$ (Fig. 4). Since no values are available between 700 and $1800 \mathrm{~m}$ we do not know whether this shift is progressive or only located at a specific depth. Cavagna et al. (2012) for the same stations, observed that the $\delta^{13} \mathrm{C}$ composition of deep ocean particles during BGH is consistent mostly with a 1-D vertical transport. This would preclude lateral advection of particles as the reason for such offset in $\mathrm{Si}$ isotopes. Consequently, it cannot be ruled out that the $\delta^{30} \mathrm{Si}_{\mathrm{bSiO}_{2}}$ particle water column profile of the WG station is biased by a progressive dissolution of biogenic silica, preferentially releasing light silicon isotopes.

2. The strong $\delta^{30} \mathrm{Si}_{\mathrm{bSiO}_{2}}$ lightening, by $0.6 \%$, below the mixed layer in the WG might result from biogenic silica produced from a subsurface $\mathrm{Si}(\mathrm{OH})_{4}$ pool with lighter $\delta^{30} \mathrm{Si}_{\mathrm{Si}(\mathrm{OH})_{4}}$, as is present at such depths (Table 1; Fripiat et al., 2011b). These depths extend below the euphotic layer (1\% PAR). Several studies have shown that energy involved in the silicification process is mainly of respiratory origin and therefore decoupled from photosynthesis (Martin-Jézéquel et al., 2000) 
allowing Si-uptake below the euphotic layer (Brzezinski et al., 1989).

\section{Conclusions}

With a palaeoceanography perspective this study has attempted to assess the controls upon, and the seasonal evolution of, biogenic silica isotopic compositions in the mixed layer and its transfer across the water column. This data set acquired in late austral summer highlights two main points:

1. A large latitudinal variation in $\delta^{30} \mathrm{Si}_{\mathrm{bSiO}_{2}}$ is observed in the mixed layer across the meridional BGH transect, contrasting with a narrower variation for $\delta^{30} \mathrm{Si}_{\mathrm{Si}(\mathrm{OH})_{4}}$. This decoupling cannot be reproduced by Rayleigh and steady-state isotopic fractionation models, which directly link the $\delta^{30} \mathrm{Si}$ to relative $\mathrm{Si}(\mathrm{OH})_{4}$ utilisation. These model failures probably result from the fact that (i) a constant isotopic fractionation is assumed over the entire period of silicate depletion and/or (ii) the seasonal expressions of the different isotopic effects are not appropriately taken into account (i.e. only Si-uptake is considered). We implemented an isotopic fractionation model to describe the seasonal $\delta^{30} \mathrm{Si}$ variation in the mixed layer. From this analysis, it seems that the exported biogenic silica is rather well described by the Rayleigh accumulated product. The failures of the existing models are especially significant at the end of the productive period when (i) biogenic silica production and export are low; (ii) $\mathrm{bSiO}_{2}$ dissolution:production ratio is high, imposing a lower apparent fractionation factor; and (iii) Si-supply:Si-uptake ratio is high. The latter effect is especially expressed when the summer mixed layer is strongly Si-depleted together with a large silicic acid vertical gradient, as is the case in the southern ACC. Despite being very hypothetical, we cannot rule out a spatial and seasonal variation in the fractionation factor associated with the net $\mathrm{bSiO}_{2}$ production. However, it seems unlikely that such variation alone is sufficient to explain the observations.

2. Except below $1800 \mathrm{~m}$ in the Weddell Gyre, where we cannot rule out a potential $\mathrm{bSiO}_{2}$ dissolution effect, the deeper $\delta^{30} \mathrm{Si}_{\mathrm{bSiO}_{2}}$ is generally similar to the mixed layer ${ }^{30} \mathrm{Si}_{\mathrm{bSiO}_{2}}$, which supports the absence of an isotopic effect during particle settling through the water column in most cases.

Acknowledgements. Our warm thanks go to the officers and crew of the R/V Marion Dufresne during the BONUS-Goodhope cruise, as well as to S. Speich and M. Boyé as program leaders. We are also grateful to J. De Jong and N. Mattielli for the management of the MC-ICP-MS laboratory at ULB and to L. Monin and N. Dahkani (RMCA) for their help in sample processing and to Virginia
Panizzo (ULB) for correction of English. This work was conducted within the BELCANTO III - BIGSOUTH networks (contracts SD/CA/03A of SPSDIII, Support Plan for Sustainable Development) funded by BELSPO, the Belgian Science Policy. Luc André thanks the "Fonds National de la Recherche Scientifique" (FNRS, Belgium) for its financial support (FRFC project 2.4512.00). François Fripiat and Anouk de Brauwere are post-doctoral fellows with the FNRS.

Edited by: A. Shemesh

\section{References}

Abraham, K., Opfergelt, S., Fripiat, F., Cavagna, A.-J., de Jong, J.T.M., Foley, S.F., André, L., and Cardinal, D.: $\delta^{30} \mathrm{Si}$ and $\delta^{29} \mathrm{Si}$ determinations on USGS BHVO-1 and BHVO-2 reference materials with a new configuration on a Nu Plasma Multi-Collector ICP-MS, Geost. Geoanal. Res., 32, 193-202, 2008.

Allison, D. B., Stramski, D., and Mitchell, B. G.: Seasonal and interannual variability of particulate organic carbon within the Southern Ocean from satellite ocean color observations, J. Geophys. Res. 115, C06002, doi:10.1029/2009JC005347, 2010.

Anderson, R. F., Chase, Z., Fleisher, M. Q., and Sachs, J.: The Southern Ocean's biological pump during the Last Glacial Maximum, Deep-Sea Res. II, 49, 1909-1938, 2002.

Anderson, R. F., Ali, S., Bradtmiller, L. I., Nielsen, S. H. H., Fleisher, M. Q., Anderson, B. E., and Burckle, L. H.: Wind-driven upwelling in the Southern Ocean and the deglacial rise in atmmospheric $\mathrm{CO}_{2}$, Science, 323, 1443-1448, doi:10.1126/science.1167441, 2009.

Beucher, C., Tréguer, P., Hapette, A.-M., and Corvaisier, R.: Intense summer Si-recycling in the surface Southern Ocean, Geophys. Res. Lett., 31, L09305, doi:10.1029/2003GL018998, 2004.

Beucher, C. P., Brzezinski, M. A., and Crosta, X.: Silicic acid dynamics in the glacial sub-Antarctic: Implications for the silicic acid leakage hypothesis, Global Biogeochem. Cy., 21, GB3015, doi:10.1029/2006GB002746, 2007.

Brzezinski, M. A. and Nelson, D. M.: Seasonal changes in the silicon cycle within a Gulf Stream warm-core ring, Deep-Sea Res., 36, 1009-1030, 1989.

Brzezinski, M. A., Nelson, D. M, Franck, V. M., and Sigmon, D. E.: Silicon dynamics within an intense open-ocean diatom bloom in the Pacific sector of the Southern Ocean, Deep-Sea Res. II, 48, 3997-4018, 2001.

Brzezinski, M. A., Pride, C. J., Franck, V. M., Sigman, D. M., Sarmiento, J. L., Matsumoto K., Gruber, N., Rau, G. H., and Coale, K. H.: A switch from $\mathrm{Si}(\mathrm{OH})_{4}$ to $\mathrm{NO}_{3}^{-}$depletion in the glacial Southern Ocean, Geophys. Res. Lett., 29, 1564, doi:10.1029/2001GL014349, 2002.

Brzezinski, M. A., Jones, J. L., Bidle, K. D., and Azam, F.: The balance between silica production and silica dissolution in the sea: Insights from Monteray Bay, California, applied to the global data set, Limnol. Oceanogr., 48, 1846-1854, 2003.

Cardinal, D., Alleman, L. Y., de Jong, J., Ziegler, K., and André, L.: Isotopic composition of silicon measured by multicollector plasma source mass spectrometry in dry plasma mode, J. Anal. Atom. Spectrom., 18, 213-218, 2003.

Cardinal, D., Alleman, L. Y., Dehairs, F., Savoye, N., Trull, T. W., and André, L.: Relevance of silicon isotopes to Si-nutrient uti- 
lization and Si-source assessment in Antarctic waters, Global Biogeochem. Cy., 19, GB2007, doi:10.1029/2004GB002364, 2005.

Cardinal, D., Savoye, N., Trull, T. W., Dehairs, F., Kopczynska, E. E., Fripiat, F., Tison, J.-L., and André, L.: Silicon isotopes in spring Southern Ocean diatoms: large zonal changes despite homogeneity among size fractions, Mar. Chem., 106, 46-62, 2007.

Cavagna, A.-J., Fripiat, F., Dehairs, F., Wolf-Gladrow, D., Cisewski, B., Savoye, N., André, L., and Cardinal, D.: Silicon uptake and supply during a Southern Ocean iron fertilization experiment (EIFEX) tracked by Si isotopes. Limnol. Oceanogr., 56, 147$160,2011$.

Cavagna, A.-J., Dehairs, F., Woule-Ebongué, V., Bouillon, S., Planchon, F., Delille, B., and Bouloubassi, I.: Whole water column distribution and carbon isotopic composition of bulk particulate organic carbon, cholesterol and brassicasterol from the Cape Basin to the northern Weddell Gyre in the Southern Ocean, Biogeosciences Discuss., 9, 1667-1709, doi:10.5194/bgd-9-16672012, 2012.

de Boyer Montégut, C., Madec, G., Fischer, A. S., Lazar, A., and Ludicone, D.: Mixed layer depth over the global ocean: An examination of profile data and a profile-based climatology, J. Geophys. Res., 109, C12003, doi:10.1029/2004JC002378, 2004.

De La Rocha, C. L.: Opal-based isotopic proxies of paleoenvironmental conditions, Global Biogeochem. Cy., 20, GB4S09, doi:10.1029/2005GB002664, 2006.

De La Rocha, C. L., Brzezinski, M. A., and DeNiro, M. J.: Purificaiton recovery and laser-driven fluorination of silicon from dissolved and particulate silica for the measurement of natural stable isotope abundances, Anal. Chem., 68, 3746-3750, 1996.

De La Rocha, C. L., Brzezinski, M. A., and DeNiro, M. J.: Fractionation of silicon isotopes by marine diatoms during biogenic silica formation, Geochim. Cosmochim. Acta, 61, 5051-5056, 1997.

De La Rocha, C. L., Brzezinski, M. A., and DeNiro, M. J.: Siliconisotope composition of diatoms as an indicator of past oceanic change, Nature, 395, 680-683, 1998.

Demarest, M. S., Brzezinski, M. A., and Beucher, C. P.: Fractionation of silicon isotopes during biogenic silica dissolution, Geochim. Cosmochim. Acta, 73, 5572-5583, doi:10.1016/j.gca.2009.06.019, 2009.

De Souza, G. F.: The marine biogeochemical cycle of silicon: insight from silicon stable isotopes, Ph.D. thesis, Swiss Federal Institute for Technology, available at: http://e-collection.library. ethz.ch/view/eth:4728, 2011.

Douthitt, C. B.: The geochemistry of the stable isotopes of silicon, Geochim. Cosmochim. Acta, 46, 1449-1458, 1982.

Faure, V., Arhan, M., Speich, S., and Gladyshev, S.: Heat budget of the surface mixed layer south of Africa, Ocean Dynamics, 61, 1441-1458, 2011.

Fripiat, F.: Isotopic approaches of the silicon cycles: The Southern Ocean case study, Ph.D. thesis, Université Libre de Bruxelles, available at: http://theses.ulb.ac.be/ETD-db/collection/available/ ULBetd-12142009-190405/, 2010.

Fripiat, F., Cavagna, A.-J., Savoye, N., Dehairs, F., André, L., and Cardinal, D.: Isotopic constraints on the Si-biogeochemical cycle of the Antarctic Zone in the Kerguelen area (KEOPS), Mar. Chem., 123, 11-22, 2011a.

Fripiat, F., Cavagna, A.-J., Dehairs, F., Speich, S., André, L., and Cardinal, D.: Silicon pool dynamics and biogenic silica export in the Southern Ocean inferred from Si-isotopes, Ocean Sci., 7, 533-547, doi:10.5194/os-7-533-2011, 2011 b.

Fripiat, F., Leblanc, K., Elskens, M., Cavagna, A.-J., Armand, L., André, L., Dehairs, F., and Cardinal, D.: Summer efficient silicon loop across the Polar Front and SubAntarctic Zones despite contrasted diatom Si-affinity, Mar. Ecol. Prog. Ser., 435, 47-61, doi:10.3354/meps09237, 2011c.

Fry, B.: Stable Isotope Ecology, Springer, New York, 308 pp., 2003.

Fütterer, D. K.: The solid phase of marine sediments, in: Marine Geochemistry, Springer, New York, 1-25, doi:10.1007/3-54032144-6_1, 2006.

Garcia, H. E., Locarnini, R. A., Boyer, T. P., and Antonov, J. I.: World Ocean Atlas 2005, Volume 4: Nutrients (phosphate, nitrate, silicate), edited by: Levitus, S., NOAA Atlas NESDIS 64, US Government Printing Office, Washington, DC, 396 pp., 2006.

Georg, R. B., Zhu, C., Reynolds, B. C., and Halliday, A. N., Stable silicon isotopes of groundwater, feldspars, and clay coating in the Navajo Sandstone aquifer, Black Mesa, Arizona, USA, Geochim. Cosmochim. Acta, 73, 2229-2241, 2009b.

Grasshof, K., Erhardt, M., and Kremling, K.: Methods of seawater analysis, 2nd ed. Verlag Chemie, Weinheim, 1983.

Hendry, K. R. and Robinson, L. F.: The relationship between silicon isotope fractionation in sponges and silicic acid concentration: Modern and core-top studies of biogenic opal, Geochim. Cosmochim. Acta, 81, 1-12, 2012.

Karl, D. M. and Tien, G.: MAGIC: a sensitive and precise method for measuring dissolved phosphorus in aquatic environments, Limnol. Oceanogr., 37, 105-116, 1992.

Krause, J. W., Brzezinski, M. A., Landry, M. R., Baines, S. B., Nelson, D. M., Selph, K. E., Taylor, A. G., and Twining, B. S., The effects of biogenic silica detritus, zooplankton grazing, and diatom size structure on silicon cycling in the euphotic zone of the eastern equatorial Pacific, Limnol. Oceanogr., 55, 2608-2622, 2010.

Martin-Jézéquel, V., Hildebrand, M., and Brzezinski, M. A.: Review: Silicon metabolism in diatoms: implications for growth, J. Phycol., 36, 821-840, 2000.

Milligan, A. J., Varela, D. E., Brzezinski, M. A., and Morel, F. M. M.: Dymanics of silicon metabolism and silicon isotopic discrimination in a marine diatom as a function of $p \mathrm{CO}_{2}$, Limnol. Oceanogr., 49, 322-329, 2004.

Moore, J. K. and Abbott, M. R.: Phytoplankton chlorophyll distributions and primary production in the Southern Ocean, J. Geophys. Res., 106, 28709-28722, 2000.

Opfergelt, S., Cardinal, D., André, L., Delvigne, C., Bremond, L., and Delvaux, B.: Variations of $\delta^{30} \mathrm{Si}$ and $\mathrm{Ge} / \mathrm{Si}$ with weathering and biogenic input in tropical basaltic ash soils under monoculture, Geochim. Cosmochim. Acta, 74, 225-240, 2010.

Pondaven, P., Fravalo, C., Ruiz-Pino, D., Tréguer, P., Quéquiner, B., and Jeandel, C.: Modelling the silica pump in the Permanently Open Ocean Zone of the Southern Ocean, J. Mar. Syst., 17, 578619, 1998.

Pondaven, P., Ruiz-Pino, D., Fravalo, C., Tréguer, P., and Jeandel, C.: Interannual variability of $\mathrm{Si}$ and $\mathrm{N}$ cycles at the time-series station KERFIX between 1990 and 1995 - a 1-D modelling study, Deep Sea Res. I, 47, 223-257, 2000.

Quéguiner, B. and Brzezinski, M. A: Biogenic silica production rates and particulate matter distribution in the Atlantic sector of the Southern Ocean During austral spring 1992, Deep-Sea Res., 
49, 1765-1786, 2002.

Ragueneau, O., Savoye, N., Del Amo, Y., Cotten, J., Tardiveau, B., and Leynaert, A.: A new method for the measurement of biogenic silica in suspended matter of coastal waters : using $\mathrm{Si}: \mathrm{Al}$ ratios to correct for the mineral interference, Cont. Shelf Res., 25, $697-$ 710,2005

Reynolds, B. C., Frank, M., and Halliday, A. N.: Silicon isotope fractionation during nutrient utilization in the North Pacific, Earth Planet. Sci. Lett., 244, 431-443, 2006.

Reynolds, B. C., Aggarwal, J., André, L., Baxter, D., Beucher, C., Brzezinski, M. A., Engström, E., Georg, R. B., Land, M., Leng, M. J., Opfergelt, S., Rodushkin, I., Sloane, H. J., van den Boorn, H. J. M., Vroon, P. Z., and Cardinal, D.: An inter-laboratory comparison of Si isotope reference materials, J. Anal. Atom. Spectrom., 22, 561-568, doi:10.1039/b616755a, 2007.

Sarmiento, J. L., Gruber, N., Brzezinski, M. A., and Dunne, J. P.: High-latitude controls of thermocline nutrients and low latitude biological productivity, Nature, 427, 56-60, 2004.

Sigman, D. M., Hain, M. P., and Haug, G. H.: The polar ocean and glacial cycles in atmospheric $\mathrm{CO}_{2}$ concentration, Nature, 466, 47-55, doi:10.1038/nature09149, 2010.

Sutton, J. N., Varela, D. E., Brzezinski, M. A., and Beucher, C.: Species-dependent silicon isotope fractionation in unialgal cultures of marine diatoms, AGU Fall Meeting 2011, PP51B-1831, 2011.
Taylor, S. R. and McLennan, S. M.: The continental crust: its composition an devolution, Blackwell Scientific Publications, Oxford, 312 pp., 1985.

Thamatrakoln, K. and Hildebrand, M.: Silicon uptake in diatoms revisited: a model for saturable and nonsaturable uptake kinetics and the role of silicon transporters, Plant. Physiol., 146, 13971407, 2008.

Tomczak, M. and Godfrey, J. S.: Regional Oceanography: An Introduction, Pergamon, New York, 2001.

Varela, D. E., Pride, C. J., and Brzezinski, M. A.: Biological fractionation of silicon isotopes in Southern Ocean surface waters, Global Biogeochem. Cy., 18, GB1047, doi:10.1029/2003GB002140, 2004.

Wille, M., Sutton, J., Ellwood, M. J., Sambridge, M., Maher, W., Eggins, S., and Kelly, M.: Silicon isotopic fractionation in marine sponges: a new model for understanding silicon fractionation in sponges, Earth Planet. Sci. Lett., 292, 281-289, doi:10.1016/j.epsl.2010.01.036, 2010.

Ziegler, K., Chadwick, O. A., Brzezinski, M. A., and Kelly, E. F.: Natural variations of $\delta^{30} \mathrm{Si}$ ratios during progressive basalt weathering, Hawaiian Islands, Geochim. Cosmochim. Acta, 69, 4597-4610, 2005. 